\title{
Applicability of the mandibular canine index for sex estimation: a systematic review
}

\author{
Maille Ferreira Nunes Rocha' ${ }^{1}$ Paulo Henrique Viana Pinto ${ }^{1}$, Ademir Franco ${ }^{2,3,4}$ and \\ Ricardo Henrique Alves da Silva ${ }^{5^{*}}$ (B)
}

\begin{abstract}
Background: The Mandibular Canine Index (MCl) comprises a method of sex estimation by teeth that presents controversial results in the literature.

Main body: This systematic review aims to expose whether $\mathrm{MCl}$ can be used as a method of reliable sex estimation. A literature search was performed using the keywords "canine," "sex,"' "gender," 'determination," "estimation," "dimorphism," "assessment," "forensic" in the databases Pubmed, Scopus, Lilacs, Scielo, and Web of Science. In addition, manual searches were carried out on the reference lists of the selected articles to cover the largest number of articles of interest as possible. Studies that performed the measurements only on maxillary canines, scientific conferences abstract books, case reports and literature reviews were excluded. The assessment of methodological quality and risk of bias was carried out based on a checklist for cross-sectional studies and another for accuracy studies. Thus, 53 articles were selected, 13 of which were accurate and 40 were cross-sectional. All accuracy articles were assessed as low risk. Among cross-sectional articles, seven were considered to be of low risk, 31 of moderate risk, and two of high risk. The accuracy of the sex estimate by $\mathrm{MCl}$ was verified and, despite varying among studies, the minimum and maximum values found were, respectively, $20 \%$ and $87.5 \%$ for women and $40.6 \%$ and $94 \%$ for men.
\end{abstract}

Conclusion: The accuracy of the $\mathrm{MCl}$ was variable and should be used with caution and as an auxiliary method of sex estimation.

Keywords: Forensic anthropology, Forensic dentistry, Odontometry, Tooth

\section{Background}

The construction of the victim's biological profile comprises an important stage of the human identification process in which knowledge of forensic anthropology is applied in order to reduce the number of potential suspects (Francisco et al. 2013). This initial screening is performed when primary identification methods need to be applied to bodies with an advanced state of decomposition, carbonized, fragmented or skeletonized, and it

\footnotetext{
*Correspondence: ricardohenrique@usp.br

${ }^{5}$ School of Dentistry of Ribeirão Preto, USP - University of São Paulo.

Postal address: Departamento de Estomatologia, Saúde Coletiva e

Odontologia Legal. Avenida do Café, s/n, Bairro Monte Alegre, Ribeirão

Preto, SP, Brazil

Full list of author information is available at the end of the article
}

prevents time and resources from being wasted (Francisco et al. 2013; Silva et al. 2015).

In extreme situations in which it is not possible to easily distinguish human remnants from non-humans (Dias et al. 2012; Oliveira et al. 2008; Silva et al. 2013), the construction of the biological profile must be initiated by determining the species so that, afterwards, parameters such as sex, age, stature and ancestry can be estimated (Silva et al. 2013). Estimating sex, in turn, is particularly important because it is an information that will guide the methods to be applied in estimating the other parameters that will form the victim's biological profile (Krishan et al. 2016; Rösing et al. 2007).

To estimate sex in adults, cranial elements can be used (Spradley and Jantz 2011) and, in forensic practice, the bones of the pelvis and skull are widely used because 
they have morphological and morphometric characteristics evidenced by pubertal hormones (Koelzer et al. 2019; Krishan et al. 2016; Rogers 2005; Rösing et al. 2007; Sinhorini et al. 2019), although the presence of youthful traits and androgenic characteristics may be present (Krishan et al. 2016; Silva et al. 2015).

In addition to the bone elements, research was carried out to ascertain or even quantify the presence of sexual dimorphism in the teeth, especially of the canine tooth in the male sex as it is evolutionarily associated with hunting activities and primate survival (Rao et al. 1989; Vijayan et al. 2019). Thus, the use of teeth in sex estimation is motivated by the resistance that these organs present, which would be particularly useful in the identification of extremely fragmented bodies or incomplete bones (Acharya et al. 2011; Azevedo et al. 2019; Vijayan et al. 2019).

Rao et al. (Rao et al. 1989) proposed a simple and practical method for sex estimation that was based on the ratio between the mesiodistal measurement of the mandibular canine tooth and the lower intercanine distance, which is why this method became known as the Mandibular Canine Index (MCI). Thus, this systematic review aims to answer the following question: the MCI can be applied as a reliable method for sex estimation of an unknown person?

\section{Main text}

\section{Material and methods Search strategy}

The searches were conducted on September 20th, 2019. In order to find relevant studies, there were no language restrictions, a range of publication year was not used, and the search was performed in the electronic databases Pubmed, Scopus, Lilacs, Scielo, and Web of Science. The search strategy was adequate for each database and the following keywords were used: canine, sex, gender, determination, estimation, dimorphism, assessment, forensic, as shown in Table 1. Manual searches were carried out on the reference lists of the selected articles to verify whether previous searches in the databases failed to identify any studies of interest.

\section{Article eligibility}

The PICO strategy (P-Population; I-Intervention; CComparison; O-Outcome) is fundamental for the construction of the appropriate research question, which determines a comprehensive bibliographic search, which incorporates the best scientific data available on the studied topic (Santos et al. 2007). Thus, this systematic review included articles that submitted patients (P), who had the sex previously known by those responsible for the research $(C)$, to certain dental measures to calculate the Mandibular Canine Index (I) in order to estimate the sex of these individuals $(\mathrm{O})$. Studies that performed the measurements only on maxillary canines, abstract books of scientific congresses, case reports, and literature reviews were excluded.

Initially, the selection was made by reading the titles and abstracts of the articles found. If the abstract was not available or if any doubts persisted regarding inclusion or not, the studies were downloaded and read in full. Some full texts were not found by manual search or using the Unpaywall software. The authors were asked to provide them via ResearchGate (http://www.researchgate.net), however, to no avail. Scientific papers found in more than one database were considered only once. The search and selection of the articles were performed by two different researchers independently. Then, the selected studies were checked by both researchers. When there was doubt about include or exclude any article, a third examiner was consulted.

\section{Assessment of quality and risk of bias}

The methodological quality assessment used two checklists proposed by The Joanna Briggs Institute: (The Joanna Briggs Institute 2017, 2020) one for cross-sectional studies, named "Checklist for Analytical Cross-Sectional

Table 1 Quantity of articles found in each database according to the search strategy

\begin{tabular}{llll}
\hline Electronic databases & Research strategies & Total \\
\hline Lilacs & (tw:(canine)) AND (tw:(sex OR gender)) AND (tw:(characteristics OR dimorphism OR estimation OR determination OR & 41 \\
& assessment AND forensic)) & & \\
Pubmed & $((($ canine) AND (sex OR gender)) AND (determination OR estimation OR dimorphism OR assessment)) AND forensic & 103 \\
Scielo & (canine) AND (sex OR gender) AND (characteristics OR dimorphism OR determination OR estimation OR assessment) & 10 \\
Scopus & AND (forensic) & & \\
Web of Science & (canine) AND (sex OR gender) AND (determination OR estimation OR dimorphism OR assessment) AND (forensic) & 1566 \\
Total & ALL=((canine) AND (sex OR gender) AND (determination OR estimation OR dimorphism OR assessment) AND (foren- & 86 \\
\hline
\end{tabular}


studies" (The Joanna Briggs Institute 2020), which has an observational design and participants are selected only by the inclusion and exclusion criteria (Setia 2016), and another directed to the accuracy studies, named "Checklist for Diagnostic Test Accuracy Studies" (The Joanna Briggs Institute 2017). In the analysis of cross-sectional studies (Table 2), topics were discussed on the details of the chosen samples, such as the inclusion and exclusion criteria, and demographic data; the measurements taken and the examiners (validity, reliability, training); possible confounding factors and on statistical analysis. When the information requested in each item was answered with "Yes," the score of $11.11 \%$ was applied; the value zero was assigned when the question received the answer " $U$ " (uncertain) and when "N/R" (not/reported) was used, the value $5.5 \%$ was determined. The percentage column relates to the percentage of "Yes" that each study presents. Thus, when the percentage of "Yes" remains below $49 \%$, the risk is considered "High"; if the percentage is between 50 and 69\%, it is classified as "Moderate"; and "Low" is applied if the percentage is equal to or greater than $70 \%$.

For the accuracy studies (Table 3), items related to the sample and the method of carrying out the measurements were verified. Regarding the samples, the surveys were evaluated according to the sampling method used and the exclusion criteria applied. For the evaluation of the measurements made, the following characteristics were observed: the blinding of the examiners, the data of the reference standard and if the time of analysis of the reference was compatible with the time of analysis of the variable of interest. In this case, when the information requested in each item was answered with "Yes," a score of $12.5 \%$ was used; the value of $6.25 \%$ was applied if the question received the answer "Unclear" and when "No" was used, the value zero was determined. The percentage column relates to the percentage of "Yes" that each study presents. Thus, when the percentage of "Yes" remains below 49\%, the risk is considered "High"; if the percentage is between 50 and $69 \%$, it is classified as "Moderate"; and "Low" is applied if the percentage is equal to or greater than $70 \%$.

\section{Results}

From the search in the electronic databases, 1806 articles were found, of which 1590 remained eligible after the removal of duplicates. Then, reading the titles and abstracts allowed to select 61 studies and, after applying the inclusion and exclusion criteria, 53 articles were included in this systematic review, as illustrated in Fig. 1. A description of the studies involved in this work containing the year of publication, title, online journal in which they were published, and the respective Quartile is shown in Table 4.

From the analysis of the methodological quality of the accuracy studies, Table 5 explains that only Rajarathnam et al. commented on the sampling method applied (Rajarathnam et al. 2016), while all articles scored positively on the items on the precaution of using case-control and inappropriate exclusions, the performance of measures in a standardized way and the inclusion of all patients in the analysis. For questions regarding the blindness of the

Table 2 Criteria for quality assessment of cross-sectional studies (The Joanna Briggs Institute 2020)

Q1) Were the criteria for inclusion in the sample clearly defined?

Q2) Were the study subjects and the setting described in detail?

Q3) Was the exposure measured in a valid and reliable way?

Q4) Were objective, standard criteria used for measurement of the condition?

Q5) Were confounding factors identified?

Q6) Were strategies to deal with confounding factors stated?

Q7) Were the outcomes measured in a valid and reliable way?

Q8) Was appropriate statistical analysis used?

Table 3 Criteria for quality assessment of accuracy studies (The Joanna Briggs Institute 2017)

Q1) Was a consecutive or random sample of patients enrolled?

Q2) Was a case control design avoided?

Q3) Did the study avoid inappropriate exclusions?

Q4) Were the index test results interpreted without knowledge of the results of the reference standard?

Q5) If a threshold was used, was it pre-specified?

Q6) Is the reference standard likely to correctly classify the target condition?

Q7) Were the reference standard results interpreted without knowledge of the results of the index test?

Q8) Was there an appropriate interval between index test and reference standard?

Q9) Did all patients receive the same reference standard?

Q10) Were all patients included in the analysis? 


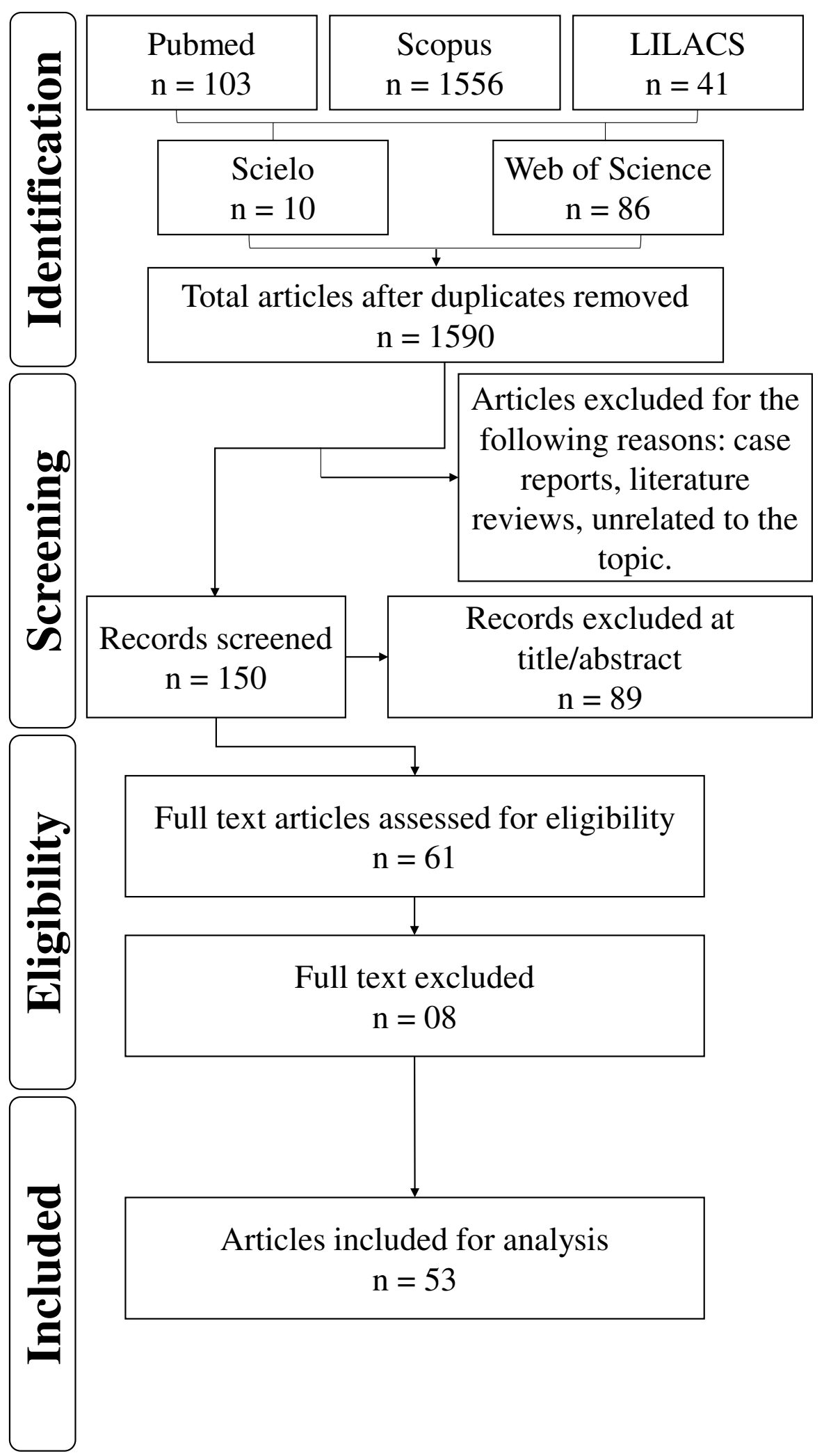

Fig. 1 Flowchart of the search results in the databases 
Table 4 Title, journal and quartile of the included articles

\begin{tabular}{|c|c|c|c|}
\hline Authors & Title & Journal & Quartile \\
\hline Acharya and Mainali 2009 & $\begin{array}{l}\text { Limitations of the mandibular canine index in sex } \\
\text { assessment }\end{array}$ & Journal of Forensic and Legal Medicine & Q1 \\
\hline Acharya et al. 2011 & $\begin{array}{l}\text { Validity of the mandibular canine index (MCI) in } \\
\text { sex prediction: Reassessment in an Indian sample }\end{array}$ & Forensic Science International & Q1 \\
\hline Anu et al. 2018 & Canine index: A tool for determination of sex & $\begin{array}{l}\text { Indian Journal of Public Health Research and } \\
\text { Development }\end{array}$ & Q4 \\
\hline Atreya et al. 2019 & $\begin{array}{l}\text { Sex predictability by using mandibular canine } \\
\text { index }\end{array}$ & Journal of Nepal Health Research Council & Q3 \\
\hline Azevedo et al. 2019 & $\begin{array}{l}\text { Sex estimation using the mandibular canine index } \\
\text { components }\end{array}$ & Forensic Science, Medicine, and Pathology & Q2 \\
\hline Bai et al. 2018 & $\begin{array}{l}\text { Correlative study on lip prints, fingerprints, and } \\
\text { mandibular intercanine distance for gender } \\
\text { determination }\end{array}$ & Journal of Forensic Dental Sciences & $-a$ \\
\hline Bakkannavar et al. 2015 & Canine index - A tool for sex determination & Egyptian Journal of Forensic Sciences & Q2 \\
\hline Dhakar et al. 2012 & $\begin{array}{l}\text { Assessment of sexual dimorphism in permanent } \\
\text { canines among different Indian ethnic groups - A } \\
\text { comparative study }\end{array}$ & $\begin{array}{l}\text { Indian Journal of Forensic Medicine and Toxicol- } \\
\text { ogy }\end{array}$ & Q3 \\
\hline Divyadharsini and Kumar 2019 & $\begin{array}{l}\text { Analysing cheiloscopic pattern and mandibular } \\
\text { canine index for gender determination }\end{array}$ & Research Journal of Pharmacy and Technology & Q3 \\
\hline Duraiswamy et al. 2009 & $\begin{array}{l}\text { Sex determination using mandibular canine index } \\
\text { in optimal-fluoride and high-fluoride areas }\end{array}$ & Journal of Forensic Dental Sciences & $-a$ \\
\hline Gandhi et al. 2017 & $\begin{array}{l}\text { Significance of mandibular canine index in sexual } \\
\text { dimorphism and aid in personal identification in } \\
\text { forensic odontology. }\end{array}$ & Journal of Forensic Dental Sciences & $-a$ \\
\hline Gargano et al. 2014 & $\begin{array}{l}\text { ¿Son los índices caninos mandibular y maxilar } \\
\text { herramientas fidedignas para la determinación } \\
\text { del sexo? }\end{array}$ & Actas Odontológicas & $-a$ \\
\hline Grover et al. 2013 & $\begin{array}{l}\text { An odontologist's key to sex determination: study } \\
\text { analysis of mandibular canine teeth in south Indian } \\
\text { population }\end{array}$ & Journal of Orofacial Research & $-a$ \\
\hline Gupta et al. 2014 & $\begin{array}{l}\text { Stature and gender determination and their corre- } \\
\text { lation using odontometry and skull anthropometry }\end{array}$ & Journal of Forensic Dental Sciences & $-a$ \\
\hline Gupta and Daniel 2016 & $\begin{array}{l}\text { Crown size and arch width dimension as an indica- } \\
\text { tor in gender determination for a Puducherry } \\
\text { population }\end{array}$ & Journal of Forensic Dental Sciences & $-a$ \\
\hline Hosmani et al. 2013 & $\begin{array}{l}\text { Reliability of Mandibular Canines as Indicators for } \\
\text { Sexual Dichotomy }\end{array}$ & Journal of International Oral Health & Q3 \\
\hline Ibeachu et al. 2012 & $\begin{array}{l}\text { Sexual dimorphism in mandibular canine width } \\
\text { and intercanine distance of University of Port- } \\
\text { Harcourt student, Nigeria }\end{array}$ & Asian Journal of Medical Sciences & $-a$ \\
\hline lqbal et al. 2015 & $\begin{array}{l}\text { Reliability of mandibular canine and mandibular } \\
\text { canine index in sex determination: A study using } \\
\text { Uyghur population }\end{array}$ & Journal of Forensic and Legal Medicine & Q1 \\
\hline Jacob et al. 2018 & $\begin{array}{l}\text { Significance of using the mandibular canine index } \\
\text { in gender determination }\end{array}$ & IOAB Journal & Q4 \\
\hline Kakkar et al. 2013 & $\begin{array}{l}\text { Study of mandibular canine index as a sex predic- } \\
\text { tor in a Punjabi population }\end{array}$ & Indian Journal of Oral Sciences & $-a$ \\
\hline Kaushal et al. 2003 & Mandibular canines in sex determination & Journal of the Anatomical Society of India & Q4 \\
\hline Kaushal et al. 2004 & $\begin{array}{l}\text { Sex determination in north Indians using man- } \\
\text { dibular canine index }\end{array}$ & Journal of Indian Academy of Forensic Medicine & Q4 \\
\hline Krishnan et al. 2016 & $\begin{array}{l}\text { Gender determination: Role of lip prints, finger } \\
\text { prints and mandibular canine index. }\end{array}$ & Experimental and Therapeutic Medicine & Q2 \\
\hline Kumawat et al. 2017 & $\begin{array}{l}\text { Mandibular canine: A tool for sex identification in } \\
\text { forensic odontology. }\end{array}$ & Journal of Forensic Dental Sciences & $-a$ \\
\hline Lagos et al. 2016 & $\begin{array}{l}\text { Sensibilidad y especificidad clínica del indice man- } \\
\text { dibular canino y del ancho mesiodistal del diente } \\
\text { canino para estimar el sexo: ajuste de un modelo } \\
\text { predictivo }\end{array}$ & International Journal of Odontostomatology & $-\mathrm{a}$ \\
\hline
\end{tabular}


Table 4 (continued)

\begin{tabular}{|c|c|c|c|}
\hline Authors & Title & Journal & Quartile \\
\hline Latif et al. 2016 & $\begin{array}{l}\text { Sex determination from mandibular canine index } \\
\text { for the age group of } 17-40 \text { years in north indian } \\
\text { population }\end{array}$ & International Journal of Scientific Study & $-a$ \\
\hline Mohsenpour et al. 2017 & $\begin{array}{l}\text { Mandibular and maxillary canine as a tool for sex } \\
\text { determination }\end{array}$ & Journal of Morphological Sciences & Q4 \\
\hline Muhamedagić and Sarajlić 2013 & $\begin{array}{l}\text { Sex determination of the Bosnian-Herzegovinian } \\
\text { population based on odontometric characteristics } \\
\text { of permanent lower canines }\end{array}$ & Journal of Health Sciences & Q4 \\
\hline Muller et al. 2001 & $\begin{array}{l}\text { Odontometrical method useful in determining } \\
\text { gender and dental alignment }\end{array}$ & Forensic Science International & Q1 \\
\hline Muthukumar and Thenmozhi 2018 & $\begin{array}{l}\text { Sex determination of an individual by studying the } \\
\text { mandibular canine index }\end{array}$ & Drug Invention Today & Q4 \\
\hline Nadendla et al. 2016 & $\begin{array}{l}\text { Identification of gender using radiomorphometric } \\
\text { measurements of canine by discriminant function } \\
\text { analysis }\end{array}$ & Indian Journal of Dental Research & Q3 \\
\hline Nagalaxmi et al. 2014 & $\begin{array}{l}\text { Cheiloscopy, palatoscopy and odontometrics in } \\
\text { sex prediction and discrimination - A comparative } \\
\text { study }\end{array}$ & Open Dentistry Journal & Q2 \\
\hline Narang et al. 2014 & $\begin{array}{l}\text { Sex determination by mandibular canine index } \\
\text { and molar odontometrics: A comparative study }\end{array}$ & Indian Journal of Oral Sciences & $-a$ \\
\hline Otuaga and Chris-Ozoko 2012 & $\begin{array}{l}\text { Sex determination in Deltans using mandibular } \\
\text { canine }\end{array}$ & Biomedical and Pharmacology Journal & Q4 \\
\hline Paramkusam et al. 2014 & $\begin{array}{l}\text { Morphometric analysis of canine in gender deter- } \\
\text { mination: revisited in India. }\end{array}$ & Indian Journal of Dental Research & Q3 \\
\hline Patel et al. 2017 & $\begin{array}{l}\text { Mandibular canine index: A study for gender } \\
\text { determination in Gandhinagar population. }\end{array}$ & Journal of Forensic Dental Sciences & $-a$ \\
\hline Patil et al. 2015 & $\begin{array}{l}\text { To evaluate the accuracy of various dental param- } \\
\text { eters used for the gender determination in Nagpur } \\
\text { District population }\end{array}$ & Indian Journal of Dental Research & Q3 \\
\hline Priyadharshini et al. 2018 & $\begin{array}{l}\text { Comparison of cheiloscopy, odontometric, and } \\
\text { facial index for sex determination in forensic } \\
\text { dentistry. }\end{array}$ & Journal of Forensic Dental Sciences & $-a$ \\
\hline Rajarathnam et al. 2016 & $\begin{array}{l}\text { Mandibular canine dimensions as an aid in gender } \\
\text { estimation. }\end{array}$ & Journal of Forensic Dental Sciences & $-a$ \\
\hline Rao et al. 1989 & $\begin{array}{l}\text { Mandibular canine index--a clue for establishing } \\
\text { sex identity }\end{array}$ & Forensic Science International & Q1 \\
\hline Reddy et al. 2008 & $\begin{array}{l}\text { Mandibular canine index as a sex determinant: A } \\
\text { study on the population of western Uttar Pradesh }\end{array}$ & Journal of Oral and Maxillo Facial Pathology & Q3 \\
\hline Sassi et al. 2012 & $\begin{array}{l}\text { Sex determination in Uruguayans by odontometric } \\
\text { analysis }\end{array}$ & Brazilian Journal of Oral Sciences & Q4 \\
\hline Shahid et al. 2018 & $\begin{array}{l}\text { Sex prediction assessment via mandibular canine } \\
\text { index and logistic regression in Pakistani popula- } \\
\text { tion: A digital model study }\end{array}$ & $\begin{array}{l}\text { Journal of International Dental and Medical } \\
\text { Research }\end{array}$ & Q3 \\
\hline Sharma and Gorea 2010 & $\begin{array}{l}\text { Importance of mandibular and maxillary canines in } \\
\text { sex determination }\end{array}$ & $\begin{array}{l}\text { Journal of Punjab Academy of Forensic Medicine } \\
\text { \& Toxicology }\end{array}$ & Q4 \\
\hline Sherfudhin et al. 1996 & $\begin{array}{l}\text { A cross-sectional study of canine dimorphism } \\
\text { in establishing sex identity: comparison of two } \\
\text { statistical methods }\end{array}$ & Journal of Oral Rehabilitation & Q1 \\
\hline Silva et al. 2016 & $\begin{array}{l}\text { A new approach to sex estimation using the man- } \\
\text { dibular canine index }\end{array}$ & Medicine, Science, and the Law & Q2 \\
\hline Singh et al. 2012 & $\begin{array}{l}\text { Sex determination using cheiloscopy and man- } \\
\text { dibular canine index as a tool in forensic dentistry }\end{array}$ & Journal of Forensic Dental Sciences & $-a$ \\
\hline Singh et al. 2015 & $\begin{array}{l}\text { Mandibular canine index: A reliable predictor for } \\
\text { gender identification using study cast in Indian } \\
\text { population }\end{array}$ & Indian Journal of Dental Research & Q3 \\
\hline Sreedhar et al. 2015 & $\begin{array}{l}\text { Dimorphic Mandibular canines in gender determi- } \\
\text { nation in Moradabad population of Western Uttar } \\
\text { Pradesh }\end{array}$ & Journal of Forensic Dental Sciences & $-a$ \\
\hline
\end{tabular}


Table 4 (continued)

\begin{tabular}{llll}
\hline Authors & Title & Journal & Quartile \\
\hline Srivastava 2010 & $\begin{array}{l}\text { Correlation of odontometric measures in sex } \\
\text { determination } \\
\text { Vijayan et al. 2019 }\end{array}$ & $\begin{array}{l}\text { Significance of mandibular canine index in sex } \\
\text { determination }\end{array}$ & International Journal of Forensic Odontology \\
Vishwakarma and Guha 2011 & $\begin{array}{l}\text { A study of sexual dimorphism in permanent } \\
\text { mandibular canines and its implications in forensic } \\
\text { investigations. }\end{array}$ & Nepal Medical College Journal & \\
Madav et al. 2002 & $\begin{array}{l}\text { Mandibular canine index in establishing sex } \\
\text { identity }\end{array}$ & Indian Journal of Dental Research \\
\hline
\end{tabular}

${ }^{\text {a Not found }}$

Table 5 Outcomes of the assessment of the risk of bias within eligible accuracy studies

\begin{tabular}{|c|c|c|c|c|c|c|c|c|c|c|c|c|}
\hline Authors & Q1 & Q2 & Q3 & Q4 & Q5 & Q6 & Q7 & Q8 & Q9 & Q10 & $\%$ & Risk \\
\hline Acharya et al. 2011 & $N / R^{a}$ & Yes & Yes & $N / R^{a}$ & $N / A^{b}$ & $N / R^{a}$ & $N / R^{a}$ & Yes & Yes & Yes & 77.55 & Low \\
\hline Azevedo et al. 2019 & $N / R^{a}$ & Yes & Yes & Yes & $N / A^{b}$ & $N / R^{a}$ & YES & Yes & Yes & Yes & 88.77 & Low \\
\hline Gupta et al. 2014 & $N / R^{a}$ & Yes & Yes & $N / R^{a}$ & $N / A^{b}$ & $N / R^{a}$ & $N / R^{a}$ & Yes & Yes & Yes & 77.55 & Low \\
\hline Gupta and Daniel 2016 & $N / R^{a}$ & Yes & Yes & $N / R^{a}$ & $N / A^{b}$ & $N / R^{a}$ & $N / R^{a}$ & Yes & Yes & Yes & 77.55 & Low \\
\hline lqbal et al. 2015 & $N / R^{a}$ & Yes & Yes & $N / R^{a}$ & $N / A^{b}$ & $N / R^{a}$ & $N / R^{a}$ & Yes & Yes & Yes & 77.55 & Low \\
\hline Jacob et al. 2018 & $N / R^{a}$ & Yes & Yes & $N / R^{a}$ & $N / A^{b}$ & $N / R^{a}$ & $N / R^{a}$ & Yes & Yes & Yes & 77.55 & Low \\
\hline Lagos et al. 2016 & $N / R^{a}$ & Yes & Yes & $N / R^{a}$ & $N / A^{b}$ & $N / R^{a}$ & $N / R^{a}$ & Yes & Yes & Yes & 77.55 & Lov \\
\hline Rajarathnam et al. 2016 & YES & Yes & Yes & $N / R^{a}$ & $N / A^{b}$ & $N / R^{a}$ & $N / R^{a}$ & Yes & Yes & Yes & 83.16 & Lon \\
\hline Sassi et al. 2012 & $N / R^{a}$ & Yes & Yes & $N / R^{a}$ & $N / A^{b}$ & $N / R^{a}$ & $N / R^{a}$ & Yes & Yes & Yes & 77.55 & Lo \\
\hline Shahid et al. 2018 & $N / R^{a}$ & Yes & Yes & $N / R^{a}$ & $N / A^{b}$ & $N / R^{a}$ & $N / R^{a}$ & Yes & Yes & Yes & 77.55 & Lo \\
\hline Sherfudhin et al. 1996 & $N / R^{a}$ & Yes & Yes & $N / R^{a}$ & $N / A^{b}$ & $N / R^{a}$ & $N / R^{a}$ & Yes & Yes & Yes & 77.55 & Lov \\
\hline Silva et al. 2016 & $N / R^{a}$ & Yes & Yes & Yes & $N / A^{b}$ & $N / R^{a}$ & YES & Yes & Yes & Yes & 88.77 & Lov \\
\hline Sreedhar et al. 2015 & $N / R^{a}$ & Yes & Yes & $N / R^{a}$ & $N / A^{b}$ & $N / R^{a}$ & $N / R^{a}$ & Yes & Yes & Yes & 77.55 & Lov \\
\hline
\end{tabular}

${ }^{\mathrm{a}}$ Not reported, ${ }^{\mathrm{b}}$ not applicable

survey examiners, the affirmative answer was received only by Azevedo et al. (Azevedo et al. 2019) and Silva et al. (Silva et al. 2016). Finally, no article scored positively in relation to the information on the reference data for comparison with those found by the studies.

It is clear that everyone reached a score above $70 \%$, and classified as low risk. Azevedo et al. (Azevedo et al. 2019) and Silva et al. (Silva et al. 2016) received the maximum score in seven of the nine questions applied, adding a percentage of $88.77 \%$. Other values received were $83.16 \%$ and $77.55 \%$ (Table 4), directed to the studies that gained the highest value in six and five items of the methodological evaluation, respectively.

The checklist for cross-sectional studies showed that only two studies did not clearly provide the inclusion and exclusion criteria. Regarding the second question, five studies did not describe the sample in detail. About the standardization of measures, all articles received a positive score; however, for the requirements on confounding factors, no article scored positively. When verifying the statistical analysis, seven studies did not clearly inform the statistical method used (Table 6).

It appears that only seven studies were considered low risk for obtaining a 75\% percentage and only Muhamedagic and Sarajlic (Muhamedagić and Sarajlić 2013) and Yadav et al. (Yadav et al. 2002) reached lower percentages, being classified as high risk. The remaining studies received percentages between 50 and $68.75 \%$ and, therefore, were identified as of moderate risk.

The samples of the selected studies involved the population of some countries in Asia, Africa, Europe, and America, with the Indians being the most investigated ( $n$ $=37$ ), and the sample size varied between 50 (Krishnan et al. 2016; Muthukumar and Thenmozhi 2018) and 1000 (Gargano et al. 2014; Jacob et al. 2018) participants. The youngest individuals analyzed were 14 years old (Dhakar et al. 2012; Duraiswamy et al. 2009; Sherfudhin et al. 1996); the most advanced age examined was 60 years old (Gargano et al. 2014; Sassi et al. 2012) and some studies (Atreya et al. 2019; Muhamedagić and Sarajlić 2013; Muller et al. 2001) did not inform the studied age group. 
Table 6 Outcomes of the assessment of the risk of bias within eligible cross-sectional studies

\begin{tabular}{|c|c|c|c|c|c|c|c|c|c|c|}
\hline Authors & Q1 & Q2 & Q3 & Q4 & Q5 & Q6 & Q7 & Q8 & $\%$ & Risk \\
\hline Acharya and Mainali 2009 & Yes & Yes & Unclear & Yes & No & No & Unclear & Yes & $62.50 \%$ & Moderate \\
\hline Anu et al. 2018 & Yes & Yes & Yes & Yes & No & No & Unclear & Yes & $68.75 \%$ & Moderate \\
\hline Atreya et al. 2019 & Yes & No & Yes & Yes & No & No & Yes & Unclear & $56.25 \%$ & Moderate \\
\hline Bai et al. 2018 & Yes & No & Unclear & Yes & No & No & Unclear & Yes & $50 \%$ & Moderate \\
\hline Bakkannavar et al. 2015 & Yes & Yes & Unclear & Yes & No & No & Unclear & Unclear & $56.25 \%$ & Moderate \\
\hline Dhakar et al. 2012 & Yes & Yes & Unclear & Yes & No & No & Unclear & Yes & $62.50 \%$ & Moderate \\
\hline Divyadharsini and Kumar 2019 & Yes & Yes & Unclear & Yes & No & No & Unclear & Yes & $62.50 \%$ & Moderate \\
\hline Duraiswamy et al. 2009 & Yes & Yes & Yes & Yes & No & No & Yes & Yes & $75 \%$ & Low \\
\hline Gandhi et al. 2017 & Yes & Yes & Yes & Yes & No & No & Yes & Yes & $75 \%$ & Low \\
\hline Gargano et al. 2014 & Yes & Yes & Yes & Yes & No & No & Yes & Yes & $75 \%$ & Low \\
\hline Grover et al. 2013 (contd.) & Yes & Yes & Yes & Yes & No & No & Yes & Unclear & $68.75 \%$ & Moderate \\
\hline Hosmani et al. 2013 & Yes & Yes & Unclear & Yes & No & No & Unclear & Yes & $62.50 \%$ & Moderate \\
\hline Ibeachu et al. 2012 & Yes & Yes & Unclear & Yes & No & No & Unclear & Yes & $62.50 \%$ & Moderate \\
\hline Kakkar et al. 2013 & Yes & Yes & Unclear & Yes & No & No & Unclear & Yes & $62.50 \%$ & Moderate \\
\hline Kaushal et al. 2003 & Yes & Yes & Unclear & Yes & No & No & Unclear & Yes & $62.50 \%$ & Moderate \\
\hline Kaushal et al. 2004 & Yes & Yes & Unclear & Yes & No & No & Unclear & Yes & $62.50 \%$ & Moderate \\
\hline Krishnan et al. 2016 & Yes & Yes & Unclear & Yes & No & No & Unclear & Yes & $62.50 \%$ & Moderate \\
\hline Kumawat et al. 2017 & Yes & Yes & Unclear & Yes & No & No & Unclear & Yes & $62.50 \%$ & Moderate \\
\hline Latif et al. 2016 & Yes & Yes & Yes & Yes & No & No & Yes & Unclear & $68.75 \%$ & Moderate \\
\hline Mohsenpour et al. 2017 & Yes & Yes & Unclear & Yes & No & No & Unclear & Yes & $62.50 \%$ & Moderate \\
\hline Muhamedaglic and Sarajlic 2013 & No & No & Unclear & Yes & No & No & Unclear & Yes & $37.50 \%$ & High \\
\hline Muller et al. 2001 & Yes & No & Yes & Yes & No & No & Yes & Yes & $62.50 \%$ & Moderate \\
\hline Muthukumar and Thenmozhi 2018 & Yes & Yes & Unclear & Yes & No & No & Unclear & Unclear & $56.25 \%$ & Moderate \\
\hline Nadendla et al. 2016 & Yes & Yes & Unclear & Yes & No & No & Unclear & Yes & $62.50 \%$ & Moderate \\
\hline Nagalaxmi et al. 2014 & Yes & No & Yes & Yes & No & No & Yes & Yes & $62.50 \%$ & Moderate \\
\hline Narang et al. 2014 & No & Yes & Unclear & Yes & No & No & Unclear & Yes & $50 \%$ & Moderate \\
\hline Otuaga and Chris-Ozoko 2012 & No & Yes & Unclear & Yes & No & No & Unclear & Yes & $50 \%$ & Moderate \\
\hline Paramkusam et al. 2014 & Yes & Yes & Unclear & Yes & No & No & Unclear & Yes & $62.50 \%$ & Moderate \\
\hline Patel et al. 2017 & Yes & Yes & Yes & Yes & No & No & Yes & Yes & $75 \%$ & Low \\
\hline Patil et al. 2015 & Yes & Yes & Unclear & Yes & No & No & Unclear & Yes & $62.50 \%$ & Moderate \\
\hline Priyadharshini et al. 2018 & Yes & Yes & Unclear & Yes & No & No & Unclear & Yes & $62.50 \%$ & Moderate \\
\hline Rao et al. 1989 & No & Yes & Unclear & Yes & No & No & Unclear & Yes & $50 \%$ & Moderate \\
\hline Reddy et al. 2008 & No & Yes & Unclear & Yes & No & No & Unclear & Yes & $50 \%$ & Moderate \\
\hline Sharma and Gorea 2010 & No & Yes & Unclear & Yes & No & No & Unclear & Yes & $50 \%$ & Moderate \\
\hline Singh et al. 2012 & Yes & Yes & Unclear & Yes & No & No & Unclear & Unclear & $56.25 \%$ & Moderate \\
\hline Singh et al. 2015 & Yes & Yes & Yes & Yes & No & No & Yes & Yes & $75 \%$ & Low \\
\hline Srivastava 2010 & Yes & Yes & Yes & Yes & No & No & Yes & Yes & $75 \%$ & Low \\
\hline Vijayan et al. 2019 & Yes & Yes & Yes & Yes & No & No & Yes & Yes & $75 \%$ & Low \\
\hline Vishwakarma and Guha 2011 & No & Yes & Unclear & Yes & No & No & Unclear & Yes & $50 \%$ & Moderate \\
\hline Yadav et al. 2002 & No & Yes & Unclear & Yes & No & No & Unclear & Unclear & $43.75 \%$ & High \\
\hline
\end{tabular}

Most of the selected studies analyzed only the right and left mandibular canines. However, some authors have also included the evaluation of the right and left maxillary canines. The measurements were performed on plaster models, digital models, radiographs and in situ evaluation. With regard to the examiners who performed the measurements, participation ranged from zero to ten in the surveys that provided this information (Table 7).

The data obtained by the studies included in this review are shown in Table 8. The lowest values found for the average of the mandibular canine index were $0.1896 \pm 0.0175$ in women and $0.1921 \pm 0.0185$ (Kakkar et al. 2013) in men, and the largest, discovered by Vijayan, Jayarajan, and 
Table 7 Description of included studies

\begin{tabular}{|c|c|c|c|c|c|c|}
\hline Study & Subjects & Age (years) & Tooth & Studied material & Examiners & Origin population \\
\hline $\begin{array}{l}\text { Acharya and Mainali } \\
2009\end{array}$ & $123(\mathrm{M}=65$ and $\mathrm{F}=58)$ & $19-28$ & 33 and 43 & Plaster models & $-^{a}$ & Nepal \\
\hline Acharya et al. 2011 & $\begin{array}{l}205(\mathrm{M}=103 \text { and } \mathrm{F}= \\
102)\end{array}$ & $19-32$ & 33 and 43 & Plaster models & $-^{\mathrm{a}}$ & India \\
\hline Anu et al. 2018 & $150(\mathrm{M}=75$ and $\mathrm{F}=75)$ & $18-22$ & $13,23,33$ and 43 & In situ & $-{ }^{a}$ & India \\
\hline Atreya et al. 2019 & $80(\mathrm{M}=40$ and $\mathrm{F}=40)$ & $-\mathrm{a}$ & 33 and 43 & Plaster models & one & Nepal \\
\hline Azevedo et al. 2019 & $120(\mathrm{M}=50$ and $\mathrm{F}=70)$ & $16-30$ & 33 and 43 & Plaster models & $-{ }^{\mathrm{a}}$ & Portugal \\
\hline Bai et al. 2018 & $\begin{array}{l}300(\mathrm{M}=150 \text { and } \mathrm{F}= \\
150)\end{array}$ & $18-25$ & 33 and 43 & Plaster models & $-^{\mathrm{a}}$ & $-^{\mathrm{a}}$ \\
\hline Bakkannavar et al. 2015 & $\begin{array}{l}500(\mathrm{M}=250 \text { and } \mathrm{F}= \\
\text { 250) }\end{array}$ & $15-25$ & $13,23,33$ and 43 & In situ & $-^{a}$ & India \\
\hline Dhakar et al. 2012 & $150(\mathrm{M}=75$ and $\mathrm{F}=75)$ & $14-20$ & 33 and 43 & Plaster models & $-^{\mathrm{a}}$ & India \\
\hline $\begin{array}{l}\text { Divyadharsini and Kumar } \\
2019\end{array}$ & $100(\mathrm{M}=50$ and $\mathrm{F}=50)$ & $19-26$ & 33 and 43 & In situ & $-^{\mathrm{a}}$ & India \\
\hline Duraiswamy et al. 2009 & 145 & $14-15$ & 33 and 43 & Plaster models & two & India \\
\hline Gandhi et al. 2017 & $62(\mathrm{M}=31$ and $\mathrm{F}=31)$ & $15-25$ & 33 and 43 & Plaster models & one & India \\
\hline Gargano et al. 2014 & $\begin{array}{l}\text { 1000 (M=501 e } F= \\
\text { 499) }\end{array}$ & $18-60$ & $13,23,33$ and 43 & Plaster models & one & Uruguay \\
\hline Grover et al. 2013 & $80(\mathrm{M}=40$ and $\mathrm{F}=40)$ & $18-20$ & 33 and 43 & In situ & two & India \\
\hline Gupta et al. 2014 & $60(\mathrm{M}=30$ and $\mathrm{F}=30)$ & $15-25$ & 33 and 43 & Plaster models & $--^{a}$ & India \\
\hline Gupta and Daniel 2016 & $106(\mathrm{M}=53$ and $\mathrm{F}=53)$ & $18-25$ & 33 and 43 & Plaster models & $--^{\mathrm{a}}$ & India \\
\hline Hosmani et al. 2013 & $100(\mathrm{M}=50$ and $\mathrm{F}=50)$ & $15-21$ & 33 and 43 & Plaster models & one & India \\
\hline Ibeachu et al. 2012 & $\begin{array}{l}300(\mathrm{M}=150 \text { and } \mathrm{F}= \\
150)\end{array}$ & $18-30$ & 33 and 43 & In situ & $-^{\mathrm{a}}$ & Nigeria \\
\hline lqbal et al. 2015 & $\begin{array}{l}216(\mathrm{M}=107 \text { and } \mathrm{F}= \\
109)\end{array}$ & $18-25$ & 33 and 43 & Plaster models & two & China \\
\hline Jacob et al. 2018 & $\begin{array}{l}1000(\mathrm{M}=500 \text { and } \mathrm{F} \\
=500)\end{array}$ & $18-25$ & 33 and 43 & Plaster models & two & India \\
\hline Kakkar et al. 2013 & $\begin{array}{l}250(M=175 \text { and } F= \\
175)\end{array}$ & $17-25$ & 33 and 43 & Plaster models & $-^{\mathrm{a}}$ & India \\
\hline Kaushal et al. 2003 & $60(\mathrm{M}=30$ and $\mathrm{F}=30)$ & $17-21$ & 33 and 43 & $\begin{array}{l}\text { In situ and plaster } \\
\text { models }\end{array}$ & $-a$ & India \\
\hline Kaushal et al. 2004 & $60(\mathrm{M}=30$ and $\mathrm{F}=30)$ & $17-21$ & 33 and 43 & In situ & $-^{\mathrm{a}}$ & India \\
\hline Krishnan et al. 2016 & $50(\mathrm{M}=25$ and $\mathrm{F}=25)$ & $18-25$ & 33 and 43 & Plaster models & $-^{\mathrm{a}}$ & India \\
\hline Kumawat et al. 2017 & $\begin{array}{l}300(\mathrm{M}=150 \text { and } \mathrm{F}= \\
150)\end{array}$ & $17-25$ & 33 and 43 & Plaster models & one & India \\
\hline Lagos et al. 2016 & $150(\mathrm{M}=65$ and $\mathrm{F}=85)$ & $18-24$ & 33 and 43 & Plaster models & $-^{a}$ & Chile \\
\hline Latif et al. 2016 & $150(\mathrm{M}=75$ and $\mathrm{F}=75)$ & $17-40$ & 33 and 43 & Plaster models & $-^{\mathrm{a}}$ & India \\
\hline Mohsenpour et al. 2017 & $100(\mathrm{M}=50$ and $\mathrm{F}=50)$ & $18-35$ & $13,23,33$ and 43 & In situ & $--^{\mathrm{a}}$ & Iran \\
\hline $\begin{array}{l}\text { Muhamedagić and } \\
\text { Sarajlić } 2013\end{array}$ & $180(\mathrm{M}=90$ and $\mathrm{F}=90)$ & $-\mathrm{a}$ & 33 and 43 & In situ & $-^{\mathrm{a}}$ & Bosnia and Herzegovina \\
\hline Muller et al. 2001 & $\begin{array}{l}424(\mathrm{M}=214 \text { and } \mathrm{F}= \\
210)\end{array}$ & $-\mathrm{a}$ & 33 and 43 & In situ & ten & France \\
\hline $\begin{array}{l}\text { Muthukumar and Then- } \\
\text { mozhi } 2018\end{array}$ & $50(\mathrm{M}=25$ and $\mathrm{F}=25)$ & $18-25$ & 33 and 43 & In situ & $--^{a}$ & India \\
\hline Nadendla et al. 2016 & $120(\mathrm{M}=60$ and $\mathrm{F}=60)$ & $20-30$ & 33 and 43 & In situ and radiography & $-^{\mathrm{a}}$ & India \\
\hline Nagalaxmi et al. 2014 & $60(\mathrm{M}=30$ and $\mathrm{F}=30)$ & $20-30$ & 33 and 43 & In situ and & two & $-^{\mathrm{a}}$ \\
\hline Narang et al. 2014 & $\begin{array}{l}410(\mathrm{M}=200 \text { and } \mathrm{F}= \\
210)\end{array}$ & $20-40$ & 33 and 43 & plaster models & one & India \\
\hline $\begin{array}{l}\text { Otuaga and Chris-Ozoko } \\
2012\end{array}$ & $\begin{array}{l}200(\mathrm{M}=100 \text { and } \mathrm{F}= \\
100)\end{array}$ & $17-21$ & 33 and 43 & In situ & $--^{\mathrm{a}}$ & Nigeria \\
\hline Paramkusam et al. 2014 & $120(\mathrm{M}=60$ and $\mathrm{F}=60)$ & $18-25$ & $13,23,33$ and 43 & $\begin{array}{l}\text { In situ and plaster } \\
\text { models }\end{array}$ & one & India \\
\hline
\end{tabular}


Table 7 (continued)

\begin{tabular}{|c|c|c|c|c|c|c|}
\hline Study & Subjects & Age (years) & Tooth & Studied material & Examiners & Origin population \\
\hline Patel et al. 2017 & $\begin{array}{l}400(\mathrm{M}=200 \text { and } \mathrm{F}= \\
\text { 200) }\end{array}$ & $21-40$ & 33 and 43 & $\begin{array}{l}\text { In situ and Plaster } \\
\text { models }\end{array}$ & three & India \\
\hline Patil et al. 2015 & 200 & $15-50$ & $13,23,33$ and 43 & In situ & $-^{a}$ & India \\
\hline Priyadharshini et al. 2018 & $100(\mathrm{M}=50$ and $\mathrm{F}=50)$ & $20-25$ & 33 and 43 & In situ & two & India \\
\hline Rajarathnam et al. 2016 & $\begin{array}{l}200(\mathrm{M}=100 \text { and } \mathrm{F}= \\
100)\end{array}$ & $18-25$ & 33 and 43 & $\begin{array}{l}\text { In situ and Plaster } \\
\text { models }\end{array}$ & $--^{a}$ & India \\
\hline Rao et al. 1989 & $\begin{array}{l}766(\mathrm{M}=382 \text { and } \mathrm{F}= \\
384)\end{array}$ & $15-21$ & 33 and 43 & In situ & two & India \\
\hline Reddy et al. 2008 & $\begin{array}{l}200(\mathrm{M}=100 \text { and } \mathrm{F}= \\
100)\end{array}$ & $17-25$ & 33 and 43 & Plaster models & $-^{a}$ & India \\
\hline Sassi et al. 2012 & $112(\mathrm{M}=56$ and $\mathrm{F}=56)$ & $21-60$ & 33 and 43 & Plaster models & one & Uruguay \\
\hline Shahid et al. 2018 & $128(\mathrm{M}=64$ and $\mathrm{F}=64)$ & $18-24$ & 33 & Plaster models & >one & Pakistan \\
\hline Sharma and Gorea 2010 & 177 & $17-50$ & $13,23,33$ and 43 & Plaster models & $-^{\mathrm{a}}$ & India \\
\hline Sherfudhin et al. 1996 & $\begin{array}{l}301(\mathrm{M}=150 \text { and } \mathrm{F}= \\
151)\end{array}$ & $14-17$ & $13,23,33$ and 43 & In situ & One & India \\
\hline Silva et al. 2016 & $120(\mathrm{M}=50$ and $\mathrm{F}=70)$ & $16-30$ & 33 and 43 & Plaster models & Two & Portugal \\
\hline Singh et al. 2012 & $60(\mathrm{M}=30$ and $\mathrm{F}=30)$ & $20-25$ & 33 and 43 & Plaster models & $-^{\mathrm{a}}$ & India \\
\hline Singh et al. 2015 & $100(\mathrm{M}=45$ and $\mathrm{F}=55)$ & $20-30$ & 33 and 43 & Plaster models & two & India \\
\hline Sreedhar et al. 2015 & $60(\mathrm{M}=30$ and $\mathrm{F}=30)$ & $19-30$ & 33 and 43 & Plaster models & $--^{\mathrm{a}}$ & India \\
\hline Srivastava 2010 & $\begin{array}{l}400(\mathrm{M}=200 \text { and } \mathrm{F}= \\
200)\end{array}$ & $17-21$ & 33 and 43 & In situ & two & India \\
\hline Vijayan et al. 2019 & $100(\mathrm{M}=50$ and $\mathrm{F}=50)$ & $18-25$ & 33 and 43 & Plaster models & one & India \\
\hline $\begin{array}{l}\text { Vishwakarma and Guha } \\
2011\end{array}$ & $180(\mathrm{M}=90$ and $\mathrm{F}=90)$ & $17-23$ & 33 and 43 & In situ & $--^{\mathrm{a}}$ & India \\
\hline Yadav et al. 2002 & $\begin{array}{l}360(\mathrm{M}=180 \text { and } \mathrm{F}= \\
\text { 180) }\end{array}$ & $15-21$ & 33 and 43 & Plaster models & $-^{\mathrm{a}}$ & India \\
\hline
\end{tabular}

${ }^{a}$ Not found

Jaleel (Vijayan et al. 2019), were $0.521 \pm 0.012$ in women and $0.444 \pm 0.010$ in men for the right mandibular canine index and $0.526 \pm 0.014$ in women and $0.447 \pm 0.012$ in men for the left mandibular canine index.

Canine sexual dimorphism was analyzed, and the highest rate found was $15.24 \%$ for the right canine, and $16.74 \%$ for the left canine (Ibeachu et al. 2012). The accuracy of the sex estimation by MCI was verified and, despite varying among studies, the minimum and maximum values found were, respectively, 20\% (Anu et al. 2018) and $87.5 \%$ (Rao et al. 1989) for women and $40.6 \%$ (Jacob et al. 2018) and 94\% (Silva et al. 2016) for men. The results found led some studies (Acharya et al. 2011; Acharya and Mainali 2009; Atreya et al. 2019; Gargano et al. 2014; Hosmani et al. 2013) to the conclusion that the canine mandibular index is not reliable for sex estimation, while others (Bakkannavar et al. 2015; Dhakar et al. 2012; Divyadharsini and Kumar 2019; Kaushal et al. 2004; Kumawat et al. 2017) guaranteed the applicability of this index in forensic practice.

\section{Discussion}

MCI is a widely researched method of sex estimation by teeth, although its practical application remains controversial. When applying MCI in different populations, divergent levels of accuracy were found (Table 8), and information related to monomorphism and reverse dimorphism of canine teeth as a result of human evolution was also reported (Boaz and Gupta 2009; Prabhu and Acharya 2009), which makes the use of MCI in forensic practice as an even more dubious method of sex estimation.

The divergence related to the use of the canine mandibular index in sex estimation is present even in studies of the same population. The Indians were the most evaluated by the studies included in this systematic review and, while some authors stated that MCI has a statistically significant sexual dimorphism, presenting rates starting at 80\% (Dhakar et al. 2012; Gandhi et al. 2017; Kaushal et al. 2004; Kumawat et al. 2017; Latif et al. 2016; Paramkusam et al. 2014; Patel et al. 2017; Rao et al. 1989; Singh et al. 2015; Sreedhar et al. 2015), others showed accuracy below 50\% (Acharya et al. 2011; Anu et al. 2018; Hosmani et al. 2013; Jacob et al. 2018; Krishnan et al. 
Table 8 Results found by the included studies

\begin{tabular}{|c|c|c|c|c|}
\hline Study & Canine index average & Canine sexual dimorphism & Accuracy of sex estimation & Population \\
\hline Acharya and Mainali 2009 & $\begin{array}{l}\text { Female: } 0.26 \\
\text { Male: } 0.26\end{array}$ & $-^{a}$ & $\begin{array}{l}\text { Female: } 44.44 \% \\
\text { Male: } 57.14 \%\end{array}$ & Nepal \\
\hline Acharya et al. 2011 & $\begin{array}{l}\text { Female: } 0.24 \\
\text { Male: } 0.24\end{array}$ & $-^{\mathrm{a}}$ & $\begin{array}{l}\text { Female: } 52 \% \\
\text { Male: } 49.51 \%\end{array}$ & India \\
\hline Anu et al. 2018 & $\begin{array}{l}\text { Female: } 0.22 \\
\text { Male: } 0.22\end{array}$ & $-^{a}$ & $\begin{array}{l}\text { Female: } 20.0 \% \\
\text { Male: } 88.0 \%\end{array}$ & India \\
\hline Atreya et al. 2019 & $\begin{array}{l}\text { Right canine: } \\
\text { Female: } 0.22 \\
\text { Male: } 0.23 \\
\text { Left canine } \\
\text { Female: } 0.22 \\
\text { Male: } 0.22\end{array}$ & $-^{a}$ & $\begin{array}{l}\text { Right } \\
\text { Female: } 60.0 \% \\
\text { Male: } 57.5 \% \\
\text { Left } \\
\text { Female: } 62.5 \% \\
\text { Male: } 57.5 \%\end{array}$ & Nepal \\
\hline Azevedo et al. 2019 & $-^{\mathrm{a}}$ & $\begin{array}{l}\text { Right canine: } 85.8 \% \\
\text { Left canine: } 85.8 \%\end{array}$ & $\begin{array}{l}\text { Right } \\
\text { Female: } 58.6 \% \\
\text { Male: } 72.0 \% \\
\text { Left } \\
\text { Female: } 57.1 \% \\
\text { Male: } 72.0 \%\end{array}$ & Portugal \\
\hline Bai et al. 2018 & $\begin{array}{l}\text { Right canine } \\
\text { Female: } 0.25 \\
\text { Male: } 0.26 \\
\text { Left canine } \\
\text { Female: } 0.25 \\
\text { Male: } 0.26\end{array}$ & $-^{a}$ & $\begin{array}{l}\text { Female: not mentioned } \\
\text { Male: } 89 \%\end{array}$ & $-^{a}$ \\
\hline Bakkannavar et al. 2015 & $\begin{array}{l}\text { Right canine } \\
\text { Female: } 0.27 \\
\text { Male: } 0.28 \\
\text { Left canine } \\
\text { Female: } 0.27 \\
\text { Male: } 0.28\end{array}$ & $-^{a}$ & $\begin{array}{l}\text { Right } \\
\text { Female: } 75.6 \% \\
\text { Male: } 73.2 \% \\
\text { Left } \\
\text { Female: } 76.8 \% \\
\text { Male: } 73.2 \%\end{array}$ & India \\
\hline Dhakar et al. 2012 & $\begin{array}{l}\text { Right canine } \\
\text { Rajasthan (Female: } 0.24 \text { /Male: } \\
0.27 \text { ) } \\
\text { Gujarat (Female: } 0.25 \text { /Male: } \\
0.27 \text { ) } \\
\text { Karnataka (Female: } 0.24 / \text { Male: } \\
0.27 \text { ) } \\
\text { Left canine } \\
\text { Rajasthan (Female: } 0.23 \text { /Male: } \\
0.26 \text { ) } \\
\text { Gujarat (Female: } 0.24 \text { /Male: } \\
0.27 \text { ) } \\
\text { Karnataka (Female: } 0.23 \text { Male: } \\
0.27 \text { ) }\end{array}$ & $-^{a}$ & $\begin{array}{l}\text { Rajasthan: } 78 \% \\
\text { Gujarat: } 76 \% \\
\text { Karnataka: 82\% }\end{array}$ & India \\
\hline Divyadharsini and Kumar 2019 & $\begin{array}{l}\text { Female: } 0.26 \\
\text { Male: } 0.27\end{array}$ & $-^{\mathrm{a}}$ & $-{ }^{\mathrm{a}}$ & India \\
\hline Duraiswamy et al. 2009 & $\begin{array}{l}\text { Right canine } \\
\text { Optimal-fluoride (Female: } \\
\text { 18.46/Male: 20.46) } \\
\text { High-fluoride (Female: 19.34/ } \\
\text { Male: 18.73) } \\
\text { Left canine } \\
\text { Optimal-fluoride (Female: } \\
\text { 19.14/Male: 21.07) } \\
\text { High-fluoride (Female: 19.34/ } \\
\text { Male: 20.10) }\end{array}$ & $-^{\mathrm{a}}$ & $-^{\mathrm{a}}$ & India \\
\hline Gandhi et al. 2017 & $\begin{array}{l}\text { Female: } 0.25036 \\
\text { Male: } 0.24808\end{array}$ & $\begin{array}{l}\text { Right canine: } 6.85 \% \\
\text { Left canine: } 7.62 \%\end{array}$ & $\begin{array}{l}\text { Female: } 83.8 \% \\
\text { Male: } 74.19 \%\end{array}$ & India \\
\hline
\end{tabular}


Table 8 (continued)

\begin{tabular}{|c|c|c|c|c|}
\hline Study & Canine index average & Canine sexual dimorphism & Accuracy of sex estimation & Population \\
\hline Gargano et al. 2014 & $\begin{array}{l}\text { Right canine } \\
\text { Female: } 0.2658 \\
\text { Male: } 0.2712 \\
\text { Left canine } \\
\text { Female: } 0.2658 \\
\text { Male: } 0.2714\end{array}$ & $--^{\mathrm{a}}$ & $\begin{array}{l}\text { Female: } 43.67 \% \\
\text { Male: } 48.1 \%\end{array}$ & Uruguay \\
\hline Grover et al. 2013 & $\begin{array}{l}\text { Right canine } \\
\text { Female: } 0.22 \\
\text { Male: } 0.25 \\
\text { Left canine } \\
\text { Female: } 0.21 \\
\text { Male: } 0.23\end{array}$ & $\begin{array}{l}\text { Right canine: } 10.11 \% \\
\text { Left canine: } 4.44 \%\end{array}$ & $\begin{array}{l}\text { Right canine: } 9.43 \% \\
\text { Left canine: } 11.81 \%\end{array}$ & India \\
\hline Gupta et al. 2014 & $\begin{array}{l}\text { Right canine } \\
\text { Female: } 0.22494 \\
\text { Male: } 0.21669 \\
\text { CANINE } \\
\text { Female: } 0.23410 \\
\text { Male: } 0.22041\end{array}$ & $-^{\mathrm{a}}$ & $--^{\mathrm{a}}$ & India \\
\hline Gupta and Daniel 2016 & $\begin{array}{l}\text { Right canine } \\
\text { Female: } 24.57 \\
\text { Male: } 26.23 \\
\text { Left canine } \\
\text { Female: } 24.77 \\
\text { Male: } 26.32\end{array}$ & $--^{a}$ & $\begin{array}{l}\text { Right } \\
\text { Female: } 77.36 \% \\
\text { Male: } 73.58 \% \\
\text { Left } \\
\text { Female: } 66.04 \% \\
\text { Male: } 67.92 \%\end{array}$ & India \\
\hline Hosmani et al. 2013 & $\begin{array}{l}\text { Female: } 0.26406 \\
\text { Male: } 0.26574\end{array}$ & $-^{\mathrm{a}}$ & $\begin{array}{l}\text { Female: } 50 \% \\
\text { Male: } 40 \%\end{array}$ & India \\
\hline Ibeachu et al. 2012 & $\begin{array}{l}\text { Right canine } \\
\text { Female: } 0.208 \\
\text { Male: } 0.228 \\
\text { Left canine } \\
\text { Female: } 0.207 \\
\text { Male: } 0.230\end{array}$ & $\begin{array}{l}\text { Right canine: } 15.24 \% \\
\text { Left canine: } 16.74 \%\end{array}$ & $-^{\mathrm{a}}$ & Nigeria \\
\hline lqbal et al. 2015 & $\begin{array}{l}\text { Female: } 0.2368 \\
\text { Male: } 0.2572\end{array}$ & $-^{\mathrm{a}}$ & $\begin{array}{l}\text { Female: } 70-97 \% \\
\text { Male: 8-73\% }\end{array}$ & China \\
\hline Jacob et al. 2018 & $\begin{array}{l}\text { Female: } 0.279 \\
\text { Male: } 0.284\end{array}$ & $--^{\mathrm{a}}$ & $\begin{array}{l}\text { Female: } 70.2 \% \\
\text { Male: } 40.6 \%\end{array}$ & India \\
\hline Kakkar et al. 2013 & $\begin{array}{l}\text { Female: } 0.1896 \\
\text { Male: } 0.1921\end{array}$ & $-^{\mathrm{a}}$ & $\begin{array}{l}\text { Female: } 55.03 \% \\
\text { Male: } 53.54 \%\end{array}$ & India \\
\hline Kaushal et al. 2003 & $\begin{array}{l}\text { Right canine } \\
\text { Casts (Female: } 0.267 / \text { Male: } \\
0.278 \text { ) } \\
\text { Intraoral (Female: } 0.267 / \text { Male: } \\
0.280 \text { ) } \\
\text { Left canine } \\
\text { Casts (Female: } 0.268 \text { /Male: } \\
0.283 \text { ) } \\
\text { Intraoral (Female: } 0.267 / \text { Male: } \\
0.282 \text { ) }\end{array}$ & $\begin{array}{l}\text { Casts } \\
\text { Right canine: } 7.96 \% \\
\text { Left canine: } 9.79 \% \\
\text { Intraoral } \\
\text { Right canine: } 7.95 \% \\
\text { Left canine: } 8.89 \%\end{array}$ & $-^{\mathrm{a}}$ & India \\
\hline Kaushal et al. 2004 & $\begin{array}{l}\text { Right canine } \\
\text { Female: } 0.26 \\
\text { Male: } 0.28 \\
\text { Left canine } \\
\text { Female: } 0.26 \\
\text { Male: } 0.28\end{array}$ & $\begin{array}{l}\text { Right canine: } 7.954 \% \\
\text { Left canine: } 8.891 \%\end{array}$ & $\begin{array}{l}\text { Right } \\
\text { Female: } 80 \% \\
\text { Male: } 70 \% \\
\text { Left } \\
\text { Female: } 83.33 \% \\
\text { Male: } 66.67 \%\end{array}$ & India \\
\hline Krishnan et al. 2016 & $--^{\mathrm{a}}$ & $-^{\mathrm{a}}$ & $\begin{array}{l}\text { Female: } 24 \% \\
\text { Male: } 84 \%\end{array}$ & India \\
\hline Kumawat et al. 2017 & $\begin{array}{l}\text { Right canine } \\
\text { Female: } 0.24 \\
\text { Male: } 0.25 \\
\text { Left canine } \\
\text { Female: } 0.24 \\
\text { Male: } 0.25\end{array}$ & $\begin{array}{l}\text { Right canine: } 5.53 \% \\
\text { Left canine: } 5.42 \%\end{array}$ & $\begin{array}{l}\text { Female: } 78 \% \\
\text { Male: } 81.33 \%\end{array}$ & India \\
\hline
\end{tabular}


Table 8 (continued)

\begin{tabular}{|c|c|c|c|c|}
\hline Study & Canine index average & Canine sexual dimorphism & Accuracy of sex estimation & Population \\
\hline Lagos et al. 2016 & $--^{\mathrm{a}}$ & $-^{\mathrm{a}}$ & $75.29 \%$ & Chile \\
\hline Latif et al. 2016 & $\begin{array}{l}\text { Female: } 0.253 \\
\text { Male: } 0.269\end{array}$ & $-^{\mathrm{a}}$ & $\begin{array}{l}\text { Female: } 76 \% \\
\text { Male: } 80 \%\end{array}$ & India \\
\hline Mohsenpour et al. 2017 & $\begin{array}{l}\text { Right canine } \\
\text { Female: } 0.2545 \\
\text { Male: } 0.2677 \\
\text { Left canine } \\
\text { Female: } 0.2567 \\
\text { Male: } 0.2704\end{array}$ & $-{ }^{\mathrm{a}}$ & $\begin{array}{l}\text { Right } \\
\text { Female: 62\% } \\
\text { Male: 44\% } \\
\text { Left } \\
\text { Female: 64\% } \\
\text { Male: 54\% }\end{array}$ & Iran \\
\hline $\begin{array}{l}\text { Muhamedagić and Sarajlić } \\
2013\end{array}$ & $\begin{array}{l}\text { Right canine } \\
\text { Female: } 0.247 \\
\text { Male: } 0.259 \\
\text { Left canine } \\
\text { Female: } 0.238 \\
\text { Male: } 0.250\end{array}$ & $--^{\mathrm{a}}$ & $\begin{array}{l}\text { Right: } 68.89 \% \\
\text { Left: } 68.54 \%\end{array}$ & Bosnia and Herzegovina \\
\hline Muller et al. 2001 & $\begin{array}{l}\text { Female: } 0.261 \\
\text { Male: } 0.275\end{array}$ & $-^{a}$ & $-^{\mathrm{a}}$ & France \\
\hline $\begin{array}{l}\text { Muthukumar and Thenmozhi } \\
2018\end{array}$ & $\begin{array}{l}\text { Right canine } \\
\text { Female: } 0.2784 \\
\text { Male: } 0.2855 \\
\text { Left canine } \\
\text { Female: } 0.2784 \\
\text { Male: } 0.2878\end{array}$ & $-^{a}$ & $\begin{array}{l}\text { Right } \\
\text { Female: } 75.6 \% \\
\text { Male: } 73.2 \% \\
\text { Left } \\
\text { Female: } 76.8 \% \\
\text { Male: } 73.2 \%\end{array}$ & India \\
\hline Nadendla et al. 2016 & $\begin{array}{l}\text { Clinical } \\
\text { Female: } 0.2630 \\
\text { Male: } 0.2614 \\
\text { Occlusal } \\
\text { Female: } 0.2765 \\
\text { Male: } 0.2625\end{array}$ & $--^{a}$ & $\begin{array}{l}\text { Clinical } \\
\text { Female: } 31.70 \% \\
\text { Male: } 76.70 \% \\
\text { Occlusal } \\
\text { Female: } 58.30 \% \\
\text { Male: } 71.70 \%\end{array}$ & India \\
\hline Nagalaxmi et al. 2014 & $\begin{array}{l}\text { Right canine } \\
\text { Female: } 0.2497 \\
\text { Male: } 0.2501 \\
\text { Left canine } \\
\text { Female: } 0.2540 \\
\text { Male: } 0.2524\end{array}$ & $\begin{array}{l}\text { Right canine: } 3.73 \% \\
\text { Left canine: } 3.06 \%\end{array}$ & $\begin{array}{l}\text { Right } \\
\text { Female: } 70.0 \% \\
\text { Male: } 73.3 \% \\
\text { LEFT } \\
\text { Female: } 56.7 \% \\
\text { Male: } 66.7 \%\end{array}$ & $--^{a}$ \\
\hline Narang et al. 2014 & $\begin{array}{l}\text { Right canine } \\
\text { Female: } 0.248 \\
\text { Male: } 0.255 \\
\text { Left canine } \\
\text { Female: } 0.241 \\
\text { Male: } 0.255\end{array}$ & $--^{\mathrm{a}}$ & $\begin{array}{l}\text { Female: } 67.6 \% \\
\text { Male: } 68.0 \%\end{array}$ & India \\
\hline Otuaga and Chris-Ozoko 2012 & $\begin{array}{l}\text { Right canine } \\
\text { Female: } 0.26 \\
\text { Male: } 0.27 \\
\text { Left canine } \\
\text { Female: } 0.26 \\
\text { Male: } 0.27\end{array}$ & $\begin{array}{l}\text { Right canine: } 8.58 \% \\
\text { Left canine: } 8.54 \%\end{array}$ & $\begin{array}{l}\text { RIGHT } \\
\text { Female: } 49.06 \% \\
\text { Male: } 50.94 \% \\
\text { LEFT } \\
\text { Female: } 49.06 \% \\
\text { Male: } 50.94 \%\end{array}$ & Nigeria \\
\hline Paramkusam et al. 2014 & $\begin{array}{l}\text { Female: } 0.26 \\
\text { Male: } 0.25\end{array}$ & $\begin{array}{l}\text { Right canine: } 8.0 \% \\
\text { Left canine: } 8.4 \%\end{array}$ & $\begin{array}{l}\text { Female: } 76.66 \% \\
\text { Male: } 80.00 \%\end{array}$ & India \\
\hline Patel et al. 2017 & $\begin{array}{l}\text { Right canine } \\
\text { Female: } 0.249 \\
\text { Male: } 0.263 \\
\text { Left canine } \\
\text { Female: } 0.249 \\
\text { Male: } 0.263\end{array}$ & $\begin{array}{l}\text { Right canine: } 8.42 \% \\
\text { Left canine: } 8.40 \%\end{array}$ & $\begin{array}{l}\text { Female: } 80.00 \% \\
\text { Male: } 77.50 \%\end{array}$ & India \\
\hline Patil et al. 2015 & $\begin{array}{l}\text { Female: } 0.319 \\
\text { Male: } 0.344\end{array}$ & $-^{\mathrm{a}}$ & $-^{\mathrm{a}}$ & India \\
\hline
\end{tabular}


Table 8 (continued)

\begin{tabular}{|c|c|c|c|c|}
\hline Study & Canine index average & Canine sexual dimorphism & Accuracy of sex estimation & Population \\
\hline Priyadharshini et al. 2018 & $\begin{array}{l}\text { Right canine } \\
\text { Female: } 0.25 \\
\text { Male: } 0.25 \\
\text { Left canine } \\
\text { Female: } 0.25 \\
\text { Male: } 0.25\end{array}$ & $-^{\mathrm{a}}$ & $-^{\mathrm{a}}$ & India \\
\hline Rajarathnam et al. 2016 & $\begin{array}{l}\text { Right canine } \\
\text { Casts (Female: } 0.25 / \text { Male: } 0.26 \text { ) } \\
\text { Intraoral (Female: } 0.25 \text { /Male: } \\
0.26 \text { ) } \\
\text { Left canine } \\
\text { Casts (Female: } 0.25 \text { /Male: } 0.26 \text { ) } \\
\text { Intraoral (Female: } 0.25 / \text { Male: } \\
0.26 \text { ) }\end{array}$ & $\begin{array}{l}\text { Right canine: } 6.90 \% \\
\text { Left canine: } 6.96 \%\end{array}$ & $73 \%$ & India \\
\hline Rao et al. 1989 & $\begin{array}{l}\text { Female: } 0.254 \\
\text { Male: } 0.296\end{array}$ & $--^{a}$ & $\begin{array}{l}\text { Female: } 87.5 \% \\
\text { Male: } 84.3 \%\end{array}$ & India \\
\hline Reddy et al. 2008 & $\begin{array}{l}\text { Right canine } \\
\text { Female: } 0.246 \\
\text { Male: } 0.259 \\
\text { Left canine } \\
\text { Female: } 0.247 \\
\text { Male: } 0.261\end{array}$ & Left canine: $9.058 \%$ & $\begin{array}{l}\text { Female: } 66 \% \\
\text { Male: } 78 \%\end{array}$ & India \\
\hline Sassi et al. 2012 & Standard value: 0.267 & $-^{\mathrm{a}}$ & $\begin{array}{l}\text { Female: } 29 \% \\
\text { Male: } 54 \%\end{array}$ & Uruguay \\
\hline Shahid et al. 2018 & $\begin{array}{l}\text { Female: } 0.26 \\
\text { Male: } 0.26\end{array}$ & $-^{\mathrm{a}}$ & $\begin{array}{l}\text { Female: } 43.70 \% \\
\text { Male: } 51.30 \%\end{array}$ & Pakistan \\
\hline Sharma and Gorea 2010 & $\begin{array}{l}\text { Right canine } \\
\text { 17-30 years (Female: } 0.259 / \\
\text { Male: } 0.265 \text { ) } \\
\text { 30-50 years (Female: } 0.252 / \\
\text { Male: } 0.256 \text { ) } \\
\text { Left canine } \\
\text { 17-30 years (Female: } 0.257 / \\
\text { Male: } 0.265 \text { ) } \\
\text { 30-50 years (Female: } 0.252 \text { / } \\
\text { Male: } 0.254 \text { ) }\end{array}$ & $\begin{array}{l}\text { RIGHT } \\
17-30 \text { years: } 5.616 \% \\
30-50 \text { years: } 4.687 \% \\
\text { LEFT } \\
17-30 \text { years: } 6.103 \% \\
3050 \text { years: } 3.882 \%\end{array}$ & $-^{\mathrm{a}}$ & India \\
\hline Sherfudhin et al. 1996 & $-^{\mathrm{a}}$ & $--^{a}$ & $\begin{array}{l}\text { Female: } 50.17 \% \\
\text { Male: } 49.83 \%\end{array}$ & India \\
\hline Silva et al. 2016 & $\begin{array}{l}\text { Female: } 0.30 \\
\text { Male: } 0.31\end{array}$ & $-^{\mathrm{a}}$ & $\begin{array}{l}\text { Female: } 25.7 \% \\
\text { Male: } 94 \%\end{array}$ & Portugal \\
\hline Singh et al. 2012 & $\begin{array}{l}\text { Right canine } \\
\text { Female: } 0.21 \\
\text { Male: } 0.21 \\
\text { Left canine } \\
\text { Female: } 0.21 \\
\text { Male: } 0.21\end{array}$ & $\begin{array}{l}\text { Right canine: } \\
6.926 \% \\
\text { Left canine: } \\
5.498 \%\end{array}$ & $--^{a}$ & India \\
\hline Singh et al. 2012 & $\begin{array}{l}\text { Right canine } \\
\text { Female: } 0.21 \\
\text { Male: } 0.21 \\
\text { Left canine } \\
\text { Female: } 0.21 \\
\text { Male: } 0.21\end{array}$ & $\begin{array}{l}\text { Right canine: } 6.926 \% \\
\text { Left canine: } \\
5.498 \%\end{array}$ & $--^{a}$ & India \\
\hline Singh et al. 2015 & $\begin{array}{l}\text { Right canine } \\
\text { Female: } 0.25 \\
\text { Male: } 0.26 \\
\text { Left canine } \\
\text { Female: } 0.25 \\
\text { Male: } 0.26\end{array}$ & $\begin{array}{l}\text { Right canine: } 14.1 \% \\
\text { Left canine: } \\
15.2 \%\end{array}$ & $\begin{array}{l}\text { Female: } 87.2 \% \\
\text { Male: } 83.8 \%\end{array}$ & India \\
\hline
\end{tabular}


Table 8 (continued)

\begin{tabular}{|c|c|c|c|c|}
\hline Study & Canine index average & Canine sexual dimorphism & Accuracy of sex estimation & Population \\
\hline Sreedhar et al. 2015 & $\begin{array}{l}\text { Right canine } \\
\text { Female: } 0.27 \\
\text { Male: } 0.25 \\
\text { Left canine } \\
\text { Female: } 0.28 \\
\text { Male: } 0.27\end{array}$ & $-^{a}$ & $\begin{array}{l}\text { Right MCl: } 84.3 \% \\
\text { Left MCl: } 75.8 \%\end{array}$ & India \\
\hline Srivastava 2010 & $\begin{array}{l}\text { Right canine } \\
\text { Female: } 0.255 \\
\text { Male: } 0.256 \\
\text { Left canine } \\
\text { Female: } 0.256 \\
\text { Male: } 0.257\end{array}$ & $\begin{array}{l}\text { Right canine: } 2.804 \% \\
\text { Left canine: } 2.326 \%\end{array}$ & $\begin{array}{l}\text { Female: } 51 \% \\
\text { Male: } 48 \%\end{array}$ & India \\
\hline Vijayan et al. 2019 & $\begin{array}{l}\text { Right canine } \\
\text { Female: } 0.521 \\
\text { Male: } 0.444 \\
\text { Left canine } \\
\text { Female: } 0.526 \\
\text { Male: } 0.447\end{array}$ & $-^{\mathrm{a}}$ & $-^{a}$ & India \\
\hline Vishwakarma and Guha 2011 & $\begin{array}{l}\text { Right canine } \\
\text { Female: } 0.2569 \\
\text { Male: } 0.2864 \\
\text { Left canine } \\
\text { Female: } 0.2645 \\
\text { Male: } 0.2888\end{array}$ & $\begin{array}{l}\text { Right canine: } 12.51 \% \\
\text { Left canine: } 10.15 \%\end{array}$ & $-^{a}$ & India \\
\hline Yadav et al. 2002 & $\begin{array}{l}\text { Female: } 0.288 \\
\text { Male: } 0.310\end{array}$ & $-^{\mathrm{a}}$ & $\begin{array}{l}\text { Female: } 81.1 \% \\
\text { Male: } 83.3 \%\end{array}$ & India \\
\hline
\end{tabular}

${ }^{\text {a Not found }}$

2016; Srivastava 2010) supporting the idea that MCI is not a significant sex estimation method.

Research carried out in Nepal (Acharya and Mainali 2009; Atreya et al. 2019), Portugal (Azevedo et al. 2019; Silva et al. 2016) and Uruguay (Gargano et al. 2014; Sassi et al. 2012) showed that the mandibular canine index showed insufficient capacity to estimate sex and should be used with caution. However, Muhamedaglic and Sarajlic tried to find out if mandibular canines could provide elements that estimate sex in the population of Bosnia and Herzegovina and reported that the right MCI indicated greater accuracy in relation to other measures (Muhamedagić and Sarajlić 2013).

This contrast can be explained by the fact that both genetic and structural formation are different between individuals, even though they are part of the same population (Jacob et al. 2018). In addition, the results for the MCI can be diverse depending on the geographic area in which each individual lives, being necessary to carry out a random sampling in each region to obtain results with greater accuracy (Singh et al. 2015).

On the other hand, the mesiodistal distance of both mandibular canine teeth, one of the components of the MCI formula, was able to estimate sex with an $85.8 \%$ level of general accuracy (78\% for males and $91.4 \%$ for the female sex), while the intercanine distance presented a level of $71.7 \%$ (74\% for the male sex and $70 \%$ for the female sex) of accuracy in the research by Azevedo et al. (Azevedo et al. 2019). When in the form of MCI, Azevedo et al. found levels of general accuracy of 63.3 and $64.2 \%$ for left and right canine teeth, respectively (Azevedo et al. 2019). Other studies (Acharya et al. 2011; Divyadharsini and Kumar 2019; Ibeachu et al. 2012; Paramkusam et al. 2014; Patil et al. 2015) also confirm the results found by Azevedo et al. when evidencing that the mesiodistal length of the canines revealed a greater degree of accuracy for sex estimation than the MCI (Azevedo et al. 2019). Questions about the influence of the intercanine distance on the accuracy of the MCI can be raised, especially if factors such as the shape of the lower dental arch, the presence of dental crowding or diastemas, or even dental movement resulting from dental absences are considered.

When thinking about the sexual dimorphism of canine, there is a disagreement about which tooth would be able to more accurately predict sex. The left canine showed a higher degree of dimorphism for some authors (Gandhi et al. 2017; Kaushal et al. 2004; Kaushal et al. 2003; Paramkusam et al. 2014; Rajarathnam et al. 2016; Reddy et al. 2008; Sharma and Gorea 2010; Singh et al. 2015) and the value of $16.74 \%$ was found by Ibeachu, Didia, and Orish for that parameter (Ibeachu, Didia and Orish et al. 2012). However, there is also evidence in the literature that the right canine provides higher rates of sexual dimorphism. 
Vishwakarma and Guha found that the right canine was more dimorphic than the left, with levels of 12.51 and 10.15\%, respectively (Vishwakarma and Guha 2011).

The applicability of the canine to differ men from women is related to the action of the $\mathrm{Y}$ chromosome, which regulates the thickness of the dentin, influencing the size of the tooth (Garn et al. 1967). However, in addition to genetic factors, the performance of ethnic, environmental, nutritional, and cultural factors can attribute to teeth's different rates of sexual dimorphism in different studies and populations (Nagalaxmi et al. 2014).

In addition, the different applied methodologies may have played an important role in the variability of the results obtained by the studies. Patel et al. performed measurements of dental dimensions in plaster models and in the individual's oral cavity in an Indian population and, when comparing them, found that plaster models contributed to a better analysis, providing a high degree of accuracy (Patel et al. 2017). On the other hand, other studies also carried out in India identified that the measurements made intraorally and in the plaster models did not differ from each other and showed to be similar and accurate (Kaushal et al. 2003; Rajarathnam et al. 2016).

The use of plaster models to perform dental measurements has advantages over intraoral analysis, since conditions such as the existence of spacing, inclined teeth, rotations, interproximal contacts, and anatomical variations can intervene in the accuracy and repeatability of measurements of teeth in the cavity oral (Zilberman et al. 2003). Thus, in addition to facilitating the analysis of measurements when the elements mentioned above are present, plaster models allow them to be examined at another time to reduce errors during measurements due to fatigue (Patel et al. 2017).

Thus, from a methodological point of view, the use of plaster models allows studies to approach the forensic routine in which the expertise teams have skeletonized or fragmented human remains. However, since the plaster model production process may suffer environmental and operator interference, it is possible that research using skeletonized human remnants of known sex may elucidate the role of $\mathrm{MCI}$ in estimating sex between different populations.

\section{Conclusions}

The accuracy of the MCI was shown to vary among different populations and even within the same population. Because of this, MCI must be considered an auxiliary method in estimating sex, but its application must be viewed with great caution. On the other hand, the mesiodistal length of the canine showed a high degree of sexual dimorphism.
Abbreviation

MCI: Mandibular Canine Index.

\section{Acknowledgements}

Not applicable

\section{Authors' contributions}

MFNR participated in the acquisition, analysis, and interpretation of data and contributed to the writing of the manuscript. PHVP also participated in the acquisition, analysis, and interpretation of data and contributed to the writing of the manuscript. AF was responsible for the conception and design of the study, supervision, and revision of the final manuscript. RHAS participated in the conception and design of the study, guidance, and review of the final manuscript, in addition to being responsible for the administration of the project. All authors mentioned above have read and approved the manuscript.

\section{Authors' information}

MFNR is graduated in Dentistry, a Forensic Odontologist and a Master's student in Pathology and Forensic Medicine at USP - University of São Paulo, School of Medicine of Ribeirão Preto.

PHVP is graduated in Dentistry, a Forensic Odontologist, a Master of Science and a PhD student in Pathology and Forensic Medicine at USP - University of São Paulo, School of Medicine of Ribeirão Preto.

AF is a Forensic Odontologist with specialization (Spec. FO), master (MSc), doctoral $(\mathrm{PhD})$ and postdoctoral training in the field. Additionally, he holds a specialization degree in Human Anatomy. AF is currently a Lecturer at the Centre of Forensic and Legal Medicine and Dentistry - University of Dundee - UK, and an invited scholar at the University of Turin - Italy, Sechenov University - Russia, and Sao Leopoldo Mandic - Brazil. His fields of expertise include Forensic Dentistry application in the interface with Oral Radiology and Anatomy. RHAS is graduated in Dentistry, a Forensic Odontologist, a Master in Dentistry in Public Health and a PhD in Social Dentistry. He is coordinator of the Specialisation Course in Forensic Dentistry and develops the following lines of research: expert human identification techniques applied to Forensic Dentistry and professional responsibility in Dentistry. He is a Brazilian Representative at the Forensic Odontology DVI INTERPOL Sub-Working Group and works as a collaborator at the Center for Legal Medicine (CEMEL/FMRP/USP) at the Forensic Anthropology Laboratory, focused on human identification. He is DirectorMember of the Brazilian Association of Ethics and Forensic Dentistry (ABOL), Brazil, and Secretary-General of the International Organization for Forensic Odonto-Stomatology (IOFOS). He is currently a professor at undergraduate and postgraduate level and a Master's and PhD advisor at the Ribeirão Preto School of Dentistry and at the Ribeirão Preto School of Medicine, both at the University of São Paulo, Brazil.

\section{Funding}

Not applicable

Availability of data and materials

Not applicable

\section{Declarations}

Ethics approval and consent to participate

Not applicable

Consent for publication

Not applicable

\section{Competing interests}

The authors declare that they have no competing interests.

\section{Author details}

${ }^{1}$ Pathology and Forensic Medicine Graduate Program, Ribeirão Preto Medical School, USP - University of São Paulo. Departamento de Patologia e Medicina Legal. Avenida Bandeirantes, Ribeirão Preto, SP n 3900, Brazil. . Division

of Forensic Dentistry, Sao Leopoldo Mandic Research Centre, R. Jose Rocha Junqueira n. 13, Campinas, SP, Brazil. ${ }^{3}$ Department of Therapeutic Stomatology, Institute of Dentistry, Sechenov University, Bolshaya Pyrogovskaya Ulitsa n. 9, Moscow, Russia. ${ }^{4}$ Centre of Forensic and Legal Medicine and Dentistry, 
School of Dentistry, University of Dundee, Nethergate DD1 4HN, Dundee, UK. ${ }^{5}$ School of Dentistry of Ribeirão Preto, USP - University of São Paulo. Postal address: Departamento de Estomatologia, Saúde Coletiva e Odontologia Legal. Avenida do Café, s/n, Bairro Monte Alegre, Ribeirão Preto, SP, Brazil.

Received: 6 January 2021 Accepted: 25 January 2022

Published online: 22 February 2022

\section{References}

Acharya AB, Angadi PV, Prabhu S, Nagnur S (2011) Validity of the mandibular canine index $(\mathrm{MCl})$ in sex prediction: reassessment in an Indian sample. Forensic Sci Int 204:207.e1-207.e4. https://doi.org/10.1016/j.forsciint. 2010.08.002

Acharya AB, Mainali S (2009) Limitations of the mandibular canine index in sex assessment. J Forensic Legal Med 16:67-69. https://doi.org/10.1016/j.jflm. 2008.08.005

Anu V, Vijayakumar A, Roy JR, Pavan VR, Kiran RR, Jas RSB, Abinaya S (2018) Canine index: a tool for determination of sex. Indian J Public Heal Res Dev 9(9):143-147. https://doi.org/10.5958/0976-5506.2018.00984.1

Atreya A, Shrestha R, Tuladhar LR, Nepal S, Shrestha R, Sah SK (2019) Sex predictability by using mandibular canine index. J Nepal Health Res Counc 17(45):501-505. https://doi.org/10.33314/jnhrc.v17i4.2187

Azevedo A, Pereira ML, Gouveia S, Tavares JN, Caldas IM (2019) Sex estimation using the mandibular canine index components. Forensic Sci Med Pathol 15:191-197. https://doi.org/10.1007/s12024-018-0051-2

Bai JKS, Prakash AR, Reddy AVS, Rajinikanth M, Sreenath S, Reddy KVKK (2018) Correlative study on lip prints, fingerprints, and mandibular intercanine distance for gender determination. J Forensic Dent Sci 10:143-150. https://doi.org/10.4103/jfo.jfds_22_16

Bakkannavar SM, Manjunath S, Nayak VC, Kumar GP (2015) Canine index - a tool for sex determination. Egypt J Forensic Sci 5:157-161. https://doi. org/10.1016/j.ejfs.2014.08.008

Boaz K, Gupta C (2009) Dimorphism in human maxillary and madibular canines in establishment of gender. J Forensic Dent Sci 1(1):42-44. https://doi.org/10.4103/0974-2948.50889

Dhakar N, Jain M, Saawarn S, Saawarn N, Madhusudan AS (2012) Assessment of sexual dimorphism in permanent canines among different Indian ethnic groups - a comparative study. Indian J Forensic Med Toxicol 6(2):123-126

Dias PEM, Beaini TL, Melani RFH (2012) Identification of a tooth-like foreign body in swine sausage. J Forensic Sci 57(5):1361-1364. https://doi.org/10. 1111/j.1556-4029.2012.02225.x

Divyadharsini V, Kumar VJ (2019) Analysing cheiloscopic pattern and mandibular canine index for gender determination. Res J Pharm Technol 12(1):254-258. https://doi.org/10.5958/0974-360X.2019.00048.9

Duraiswamy P, Tibdewal H, Patel K, Kumar S, Dhanni C, Kulkarni S (2009) Sex determination using mandibular canine index in optimal-fluoride and high-fluoride areas. J Forensic Dent Sci 1(2):99-103. https://doi.org/10. 4103/0974-2948.60382

Francisco RA, Silva RHA, Pereira JM, Soares EG, Matheucci E Jr, Iwamura ESM, Guimarães MA (2013) Forensic anthropology screening for analyses of forensic genetics. Saúde, Ética \& Justiça 18(1):128-133. https://doi.org/10. 11606/issn.2317-2770.v18i1p128-133

Gandhi N, Jain S, Kahlon H, Singh A, Gambhir RS, Gaur A (2017) Significance of mandibular canine index in sexual dimorphism and aid in personal identification in forensic odontology. J Forensic Dent Sci 9:56-60. https:// doi.org/10.4103/jfo.jfds_15_16

Gargano V, Picapedra A, Sassi C, Lima LNC, Alvarez R, Francesquini Júnior L, Daruge Júnior E (2014) Are mandibular and maxillary canine indexes reliable tools for sex determination? Acta Odontol 11(2):22-34

Garn SM, Lewis AB, Swindler DR, Kerewsky RS (1967) Genetic control of sexual dimorphism in tooth size. J Dent Res 46(5):963-972. https://doi.org/10. 1177/00220345670460055801

Grover M, Bai RG, Ram T, Puri PM, Ghodke KR (2013) An Odontologist's key to sex determination: study analysis of mandibular canine teeth in south Indian population. J Orofac Res 3(3):157-160. https://doi.org/10.5005/ jp-journals-10026-1087

Gupta A, Kumar K, Shetty DC, Wadhwan V, Jain A, Khanna KS (2014) Stature and gender determination and their correlation using odontometry and skull anthropometry. J Forensic Dent Sci 6(2):101-106. https://doi.org/10. 4103/0975-1475.132536

Gupta J, Daniel MJ (2016) Crown size and arch width dimension as an indicator in gender determination for a Puducherry population. J Forensic Dent Sci 8:120-125. https://doi.org/10.4103/0975-1475.195105

Hosmani JV, Nayak RS, Kotrashetti VS, Pradeep S, Babji D (2013) Reliability of mandibular canines as indicators for sexual dichotomy. J Int Oral Health 5(1):1-7

Ibeachu PC, Didia BC, Orish C (2012) Sexual dimorphism in mandibular canine width and intercanine distance of University of Port-Harcourt student, Nigeria. Asian J Med Sci 2(5):166-169

lqbal R, Zhang S, Mi C (2015) Reliability of mandibular canine and mandibular canine index in sex determination: a study using Uyghur population. J Forensic Legal Med 33:9-13. https://doi.org/10.1016/j.jfm.2015.03.007

Jacob C, Izadpanahian E, Jadhav M, Patil A (2018) Significance of using the mandibular canine index in gender determination. IIOAB J 9(5):9-12

Kakkar T, Sandhu S, Sekhon A, Singla K, Bector K, Sandhu J (2013) Study of mandibular canine index as a sex predictor in a Punjabi population. Indian J Oral Sci 4(1):23-26. https://doi.org/10.4103/0976-6944.118518

Kaushal S, Patnaik WG, Agnihotri G (2003) Mandibular canines in sex determination. J Anat Soc India 52(2):119-124

Kaushal S, Patnaik VG, Sood V, Agnihotri G (2004) Sex determination in north Indians using mandibular canine index. J Indian Acad Forensic Med 26(2):45-49

Koelzer SC, Kuemmel IV, Koelzer JT, Ramsthaler F, Holz F, Gehl A, Verhoff MA (2019) Definitions of frontal bone inclination: applicability and quantification. Forensic Sci Int 303:109929. https://doi.org/10.1016/j.forsciint.2019. 109929

Krishan K, Chatterjee PM, Kanchan T, Kaur S, Baryah N, Singh RK (2016) A review of sex estimation techniques during examination of skeletal remains in forensic anthropology casework. Forensic Sci Int 261:165. e1-165.e8. https://doi.org/10.1016/j.forsciint.2016.02.007

Krishnan RP, Thangavelu R, Rathnavelu V, Narasimhan M (2016) Gender determination: role of lip prints, finger prints and mandibular canine index. Exp Ther Med 11(6):2329-2332. https://doi.org/10.3892/etm.2016.3245

Kumawat RM, Dindgire SL, Gadhari M, Khobragade PG, Kadoo PS, Yadav P (2017) Mandibular canine: a tool for sex identification in forensic odontology. J Forensic Dent Sci 9(2):109. https://doi.org/10.4103/jfo.jfds_41_16

Lagos D, Ciocca L, Cáceres D (2016) Sensibilidad y especificidad clínica del indice mandibular canino y del ancho mesiodistal del diente canino Para estimar el sexo: ajuste de un Modelo predictivo. Int J Odontostomat 10(2):177-183. https://doi.org/10.4067/S0718-381X2016000200001

Latif M, Rashid W, Kaur B, Aggarwal A, Rashid A (2016) Sex determination from mandibular canine index for the age group of 17-40 years in north Indian population. Int J Sci Study 4(2):141-147. https://doi.org/10.17354/ijss/ 2016/271

Mohsenpour K, Gangadhar MR, Samehsalari S (2017) Mandibular and maxillary canine as a tool for sex determination. J Morphol Sci 34(4):247-250. https://doi.org/10.4322/jms.114217

Muhamedagić B, Sarajlić N (2013) Sex determination of the Bosnian-Herzegovinian population based on odontometric characteristics of permanent lower canines. J Health Sci 3(2):164-169. https://doi.org/10.17532/jhsci. 2013.82

Muller M, Lupi-Pegurier L, Quatrehomme G, Bolla M (2001) Odontometrical method useful in determining gender and dental alignment. Forensic Sci Int 121(3):194-197. https://doi.org/10.1016/s0379-0738(01)00399-1

Muthukumar A, Thenmozhi MS (2018) Sex determination of an individual by studying the mandibular canine index. Drug Invent Today 10(Special Issue 1):2622-2625

Nadendla L, Paramkusam G, Pokala A, Devulapalli R (2016) Identification of gender using radiomorphometric measurements of canine by discriminant function analysis. Indian J Dental Res 27(1):27-31. https://doi.org/10. 4103/0970-9290.179810

Nagalaxmi V, Sridevi U, Jyothi MN, Lalitha C, Naik MK, Srikanth K (2014) Cheiloscopy, palatoscopy and odontometrics in sex prediction and discrimination - a comparative study. Open Dent J 8(1):269-279. https://doi.org/10. 2174/1874210601408010269

Narang R, Manchanda A, Bhatia H, Malhotra R (2014) Sex determination by mandibular canine index and molar odontometrics: a comparative study. Indian J Oral Sci 5(1):16-20. https://doi.org/10.4103/0976-6944.129944 
Oliveira RN, Silva RHA, Boldrini SC (2008) Pericial analysis of a dental element found inside food used for human consumption. J Forensic Legal Med 15:269-273. https://doi.org/10.1016/j.jlm.2007.10.007

Otuaga PO, Chris-Ozoko LE (2012) Sex determination in Deltans using mandibular canine. Biomed Pharmacol J 5(1):111-115. https://doi.org/10. 13005/bpj/329

Paramkusam G, Nadendla LK, Devulapalli RV, Pokala A (2014) Morphometric analysis of canine in gender determination: revisited in India. Indian J Dent Res 25(4):425-429. https://doi.org/10.4103/0970-9290.142514

Patel RA, Chaudhary AR, Dudhia BB, Macwan ZS, Patel PS, Jani YV (2017) Mandibular canine index: a study for gender determination in Gandhinagar population. J Forensic Dent Sci 9(3):135-143. https://doi.org/10.4103/jfo. jfds 6416

Patil SN, Naik SB, Kamble SD, Kokane VB (2015) To evaluate the accuracy of various dental parameters used for the gender determination in Nagpur District population. Indian J Dent Res 26(6):576-581. https://doi.org/10. 4103/0970-9290.176918

Prabhu S, Acharya AB (2009) Odontometric sex assessment in Indians. Forensic Sci Int 192(1-3):129.e1-129.e5. https://doi.org/10.1016/j.forsciint.2009. 08.008

Priyadharshini Kl, Ambika M, Sekar B, Mohanbabu V, Sabarinath B, Pavithra I (2018) Comparison of cheiloscopy, odontometric, and facial index for sex determination in forensic dentistry. J Forensic Dent Sci 10(2):88-91. https://doi.org/10.4103/jfo.jfds_102_17

Rajarathnam BN, David MP, Indira AP (2016) Mandibular canine dimensions as an aid in gender estimation. J Forensic Dent Sci 8(2):83-89. https://doi. org/10.4103/0975-1475.186364

Rao NG, Rao NN, Pai ML, Kotian MS (1989) Mandibular canine index--a clue for establishing sex identity. Forensic Sci Int 42:249-254. https://doi.org/10. 1016/0379-0738(89)90092-3

Reddy V, Saxena S, Bansal P (2008) Mandibular canine index as a sex determinant: a study on the population of western Uttar Pradesh. J Oral Maxillofac Pathol 12(2):56-59. https://doi.org/10.4103/0973-029x.44577

Rogers TL (2005) Determining the sex of human remains through cranial morphology. J Forensic Sci 50(3):493-500

Rösing FW, Graw M, Marré B, Ritz-Timme S, Rothschild MA, Rötzscher K, Schmeling A, Schröder I, Geserick G (2007) Recommendations for the forensic diagnosis of sex and age from skeletons. HOMO 58:75-89. https://doi.org/10.1016/j.jchb.2005.07.002

Santos C, Pimenta C, Nobre M (2007) The PICO strategy for the research question construction and evidence search. Rev Lat Am Enfermagem 15(3):508-511. https://doi.org/10.1590/S0104-11692007000300023

Sassi C, Picapedra A, Lima LNC, Francesquini Júnior L, Daruge E, Daruge Júnior E (2012) Sex determination in Uruguayans byodontometric analysis. Braz J Oral Sci 11(3):381-386

Setia MS (2016) Methodology series module 3: cross-sectional studies. Indian J Dermatol 61:261-264. https://doi.org/10.4103/0019-5154.182410

Shahid F, Khamis MF, Alam MK (2018) Sex prediction assessment via mandibular canine index and logistic regression in Pakistani population: a digital model study. J Int Dent Medical Res 11(2):503-509

Sharma M, Gorea R (2010) Importance of mandibular and maxillary canines in sex determination. J Punjab Acad Forensic Med Toxicol 10(1):27-30

Sherfudhin H, Abdullah MA, Khan N (1996) A cross-sectional study of canine dimorphism in establishing sex identity: comparison of two statistical methods. J Oral Rehabil 23(9):627-631. https://doi.org/10.1046/j.13652842.1996.00406.x

Silva AM, Pereira ML, Gouveia S, Tavares JN, Azevedo A, Caldas IM (2016) A new approach to sex estimation using the mandibular canine index. Med Sci Law 56(1):7-12. https://doi.org/10.1177/0025802415575415

Silva RF, Dias PEM, Picoli FF, Rodrigues LG, Mundim MBV, Franco A (2015) Anthropological discrepancies detected in putrefied bodyidentified with dental records -a case report. RBOL 2(1):125-136. https://doi.org/10. 21117/rbol.v2i1.25

Silva RF, Mendes SDSC, Marinho DEA, Rosário Júnior AF, Guimarães MA (2013) Importance of the comparative anatomy in forensic anthropology - case report. RSBO 10(2):193-197

Singh J, Gupta KD, Sardana V, Balappanavar AY, Malhotra G (2012) Sex determination using cheiloscopy and mandibular canine index as a tool in forensic dentistry. J Forensic Dent Sci 4(2):70-74. https://doi.org/10.4103/ 0975-1475.109889
Singh SK, Gupta A, Padmavathi BN, Kumar S, Roy S, Kumar A (2015) Mandibular canine index: a reliable predictor for gender identification using study cast in Indian population. Indian J Dent Res 26(4):396-399. https://doi. org/10.4103/0970-9290.167632

Sinhorini PA, Costa IAP, Lopez-Capp TT, Biazevic MGH, Paiva LAS (2019) Comparative analysis of four morphometric methods for sex estimation: a study conducted on human skulls. Legal Med 39:29-34. https://doi.org/ 10.1016/j.legalmed.2019.06.001

Spradley MK, Jantz RL (2011) Sex estimation in forensic anthropology: skull versus postcranial elements. J Forensic Sci 56(2):289-296. https://doi.org/ 10.1111/j.1556-4029.2010.01635.x

Sreedhar G, Sumalatha MN, Ramesh G, Nagarajappa R, Murari A, Agrawal A (2015) Dimorphic mandibular canines in gender determination in Moradabad population of Western Uttar Pradesh. J Forensic Dent Sci 7(1):32-36. https://doi.org/10.4103/0975-1475.150302

Srivastava P (2010) Correlation of odontometric measures in sex determination. J Indian Acad Forensic Med 32(1):56-61

The Joanna Briggs Institute (2017) Checklist for diagnostic test accuracy studies. Available from: https://joannabriggs.org/critical-appraisal-tools (Accessed 23 Apr 2020).

The Joanna Briggs Institute (2020) Checklist for analytical cross sectional studies. Available from: https://joannabriggs.org/critical-appraisal-tools (Accessed 23 Apr 2020).

Vijayan A, Jayarajan J, Jaleel BNF (2019) Significance of mandibular canine index in sex determination. Int J Forensic Odontol 4:54-58. https://doi. org/10.4103/ijfo.ijfo_13_19

Vishwakarma N, Guha R (2011) A study of sexual dimorphism in permanent mandibular canines and its implications in forensic investigations. Nepal Med Coll J 13(2):96-99

Yadav S, Nagabhushana D, Rao BB, Mamatha GP (2002) Mandibular canine index in establishing sex identity. Indian J Dent Res 13(3-4):143-146

Zilberman O, Huggare JÅV, Parikakis KA (2003) Evaluation of the validity of tooth size and arch width measurements using conventional and threedimensional virtual orthodontic models. Angle Orthod 73(3):301-306 (https://doi.org/10.1043/0003-3219(2003)073<0301:EOTVOT>2.0.CO;2)

\section{Publisher's Note}

Springer Nature remains neutral with regard to jurisdictional claims in published maps and institutional affiliations.

\section{Submit your manuscript to a SpringerOpen ${ }^{\circ}$ journal and benefit from:}

- Convenient online submission

- Rigorous peer review

- Open access: articles freely available online

- High visibility within the field

- Retaining the copyright to your article

Submit your next manuscript at springeropen.com 